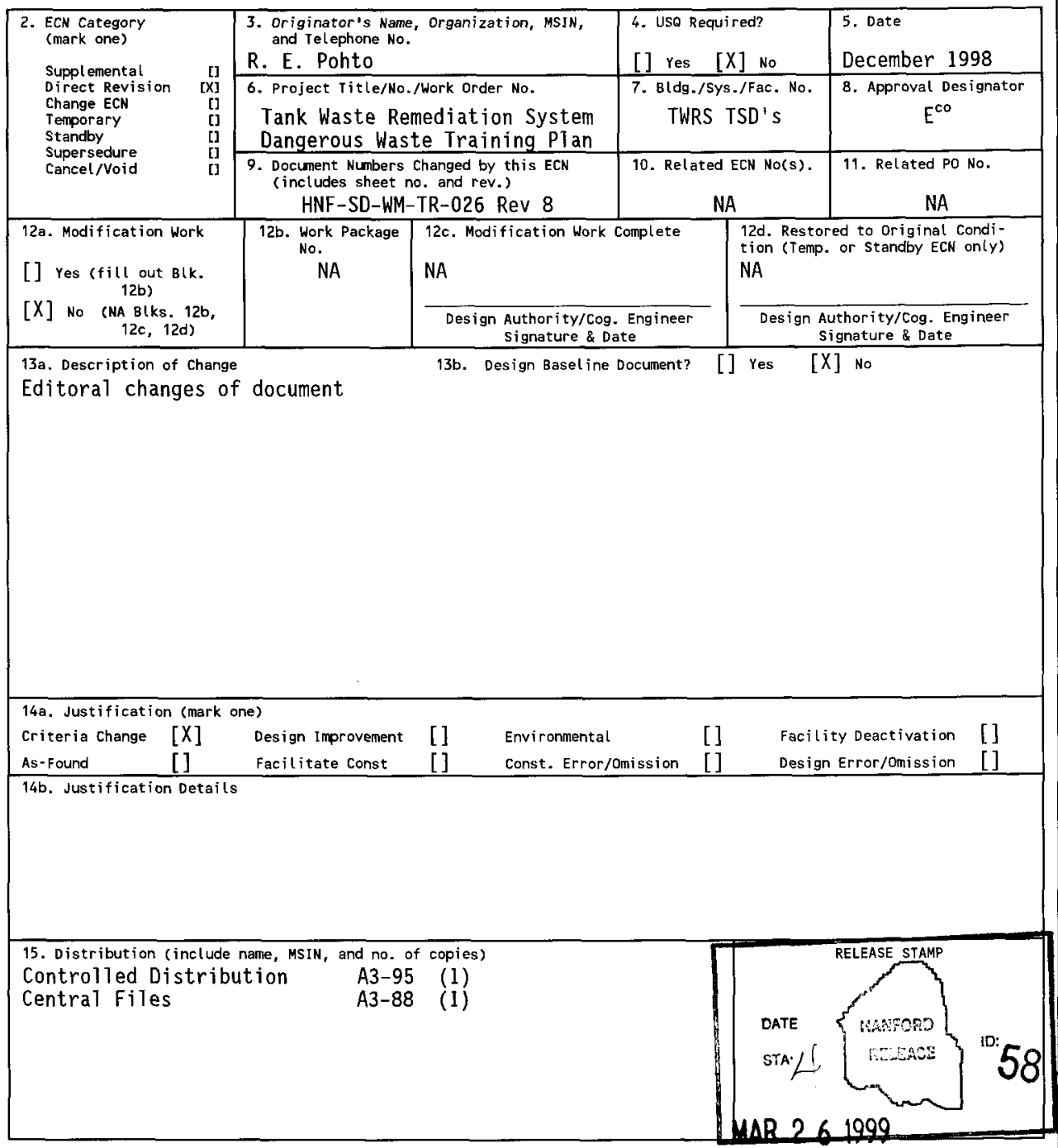

A-7900-013-2 (05/96) GEF095 
16. Design
Verification Required [] Yes
$[X]$ No

17. Cost Impact
ENGINEERING
$\begin{array}{lll}\text { Additional } & {[]} & \$ \\ \text { Savings } & {[]} & \$\end{array}$

CONSTRUCTION 610887

18. Schedule Impact (days)

Improvement

[]

Delay

19. Change Impact Review: Indicate the related documents (other than the engineering documents identified on side 1 ) that will be affected by the change described in Block 13 . Enter the affected document number in Block 20.

$$
\text { SDD/OD }
$$

Functional Design Criteria

Operating Specification

Criticality Specification

Conceptual Design Report

Equipment Spec.

Const. Spec

Procurement Spec.

Vendor Information

OM Manual

FSAR/SAR

Safety Equipment List

Radiation Work Permit

Environmental Impact Statement

Environmental Report

Environmental Permit
[] Seismic/Stross Analysis

[]

[]

[]

[]

[]

[]

[]

[]

[]

[]

[]

[]

[]

[]

Cell Arrangement Drawing

Fac. Proc. Samp. Schedule

Inspection Plan

Inventory Adjustment Request
[]

[]

[]

[]

[]

[]

[]

[]

[]

[]

[]

[]

[]

[]

[]

Tank Calibration Manual

Health Physics Procedure

Spares Multiple Unit Listing

Test Procedures/Specification

Component Index

ASME Coded Item

Human Factor Consideration

Computer Software

Electric Circuit Schedule

ICRS Procedure

Process Control Manual/Plan

Process Flow Chart

Purchase Requisition

Tickler File

[]

[]

[]

[]

20. Other Affected Documents: (NOTE: Documents listed below will not be revised by this ECN.) Signatures below indicate that the signing organization has been notified of other affected documents listed below. Document Number/Revision Document Number/Revision Document Number Revision

HNF-IP-0974 Rev 14

21. Approvals

Cog. Eng. RE pohto signafure $Q . \&$.

Date

$\frac{3-3-99}{3-24-99}$

Signature

Date

Cog. Mgr. BG Erlandson

Safety

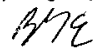

Environ. $\beta / \varepsilon$

TWRS operations

characterization Project operations $A$ foln keor

eperoting-tacitios

Training

Tank Farm Maintenance

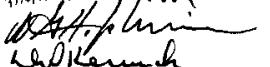

$\frac{3124 / 9}{3 / 24 / 99}$
$\frac{3 / 24 / 99}{3 / 17 / 90}$
$\frac{3 / 8 / 99}{3 / 23199}$ 


\title{
Tank Waste Remediation System Dangerous Waste Training Plan
}

\author{
RE Pohto \\ Lockheed Martin Hanford Corporation, Richland, WA 99352 \\ U.S. Department of Energy Contract DE-AC06-96RL13200
}

EDT/ECN: 610887

Org Code: 79600

UC: 2030

B\&R Code: EW3120071

Charge Code: 101785

Total Pages: 7476

Key Words: Dangerous Waste, RCRA, WAC 173-303

Abstract: This supporting document contains the training plan for dangerous waste management at Tank Waste Remediation Systems TSD Units

TRADEMARK DISCLAIMER. Reference herein to any specific comercial product, process, or service by trade name, trademark, manufacturer, or otherwise, does not necessarily constitute or imply its endorsement, recommendation, or favoring by the United States Government or any agency thereof or its contractors or subcontractors.

Printed in the United States of America. To obtain copies of this document, contact: Document Control Services, P.O. Box 950, Mailstop H6-08, Richland WA 99352, Phone (509) 372-2420; Fax (509) 376-4989.
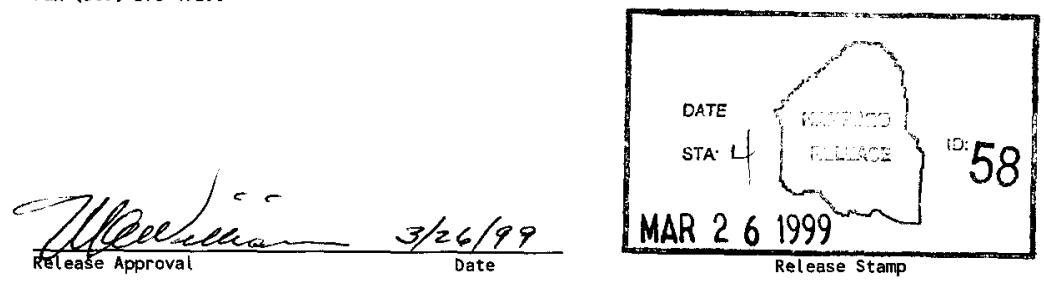

\section{Approved for Public Release}


RECORD OF REVISION

(1) Document Number

HNF-SD-WM-TR-026

Page 1

(2) Title

Tank Waste Remediation System Dangerous Waste Training Plan

CHANGE CONTROL RECORD

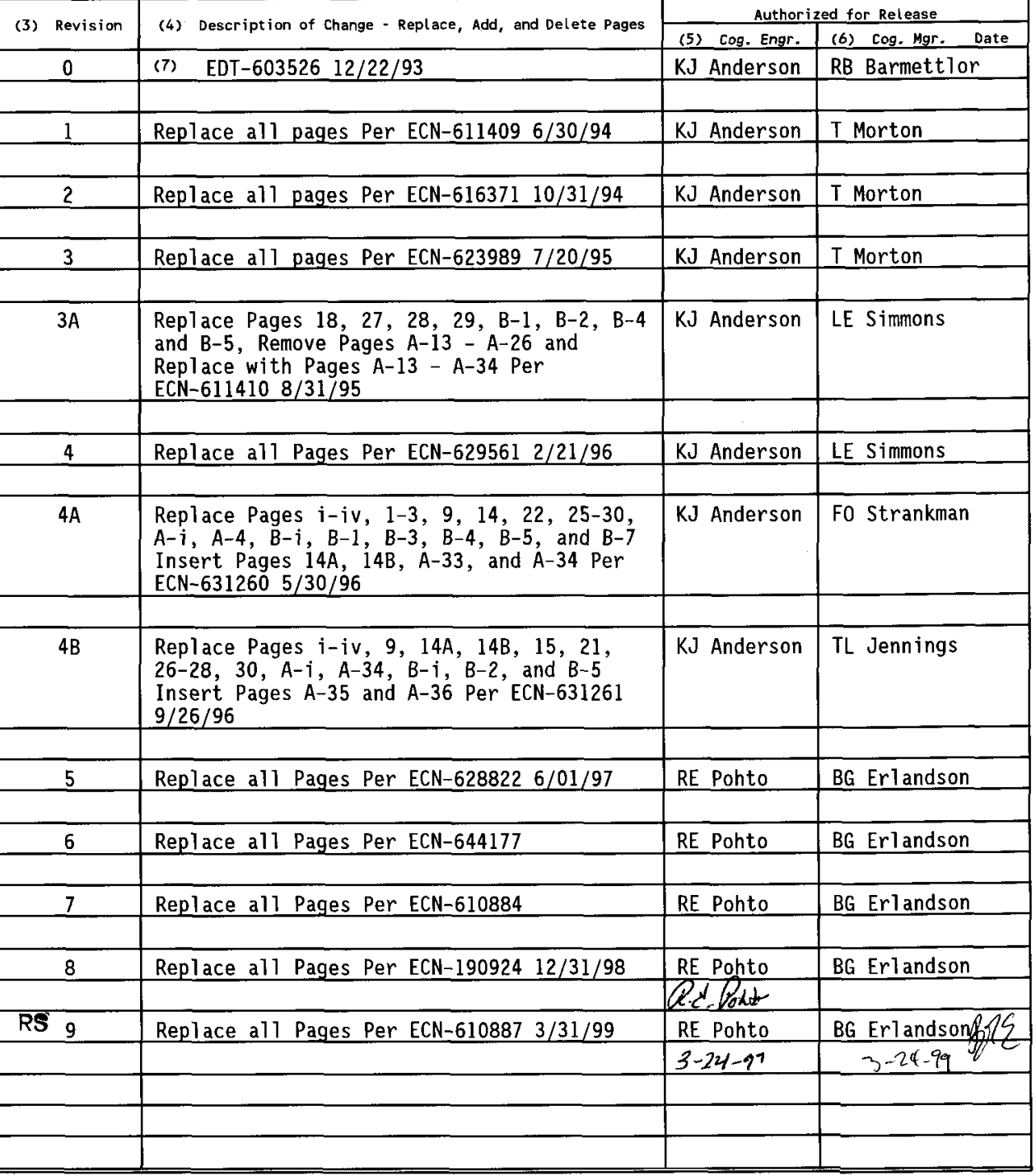


HNF-SD-WM-TR-026

Revision 9

\section{Tank Waste Remediation System Dangerous Waste Training Plan}

R. E. Pohto

Lockheed Martin Hanford Corp.

Date Published

March 1999

Prepared for the U.S. Department of Energy

TLOOR DANIEL haNroRd, Inc.
P.O. Box 1000

Richland, Washington

Hanford Management and Integration Contractor for the

U.S. Department of Energy under Contract DE-ACO6-96RL13200

Approved for Public Release; Further Dissemination Unlimited 
HNF-SD-WM-TR-026 Rev. 9

TANK WASTE REMEDIATION SYSTEM

DANGEROUS WASTE TRAINING PLAN

March 1999

TWRS Environmental 


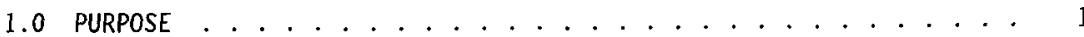

2.0 RESPONSIBILITIES ..................... . . . 1

2.1 TWRS Responsibilities............. 1

2.2 Training Organization Responsibilities ......... 2

2.3 Environmental Organization Responsibilities ........ 2

2.4 Flour Daniel Northwest Responsibilities......... 2

3.0 IMPLEMENTATION OF TRAINING PROGRAM .............. 2

3.1 Identification of Training .............. 3

3.2 Conduct of Training . . . . . . . . . . . . 3

3.3 Evaluation of Training .............. 3

3.4 Documentation of Training . . . . . . . . . . 3

4.0 DANGEROUS WASTE WORKER CATEGORIES ................ 4

5.0 JOB POSITIONS AND DESCRIPTIONS . . . . . . . . . . . 7

5.1 All Employees. ................... . . 7

5.2 General Worker ................ 7

5.3 Advanced General Worker . . . . . . . . . . . . . . . 8

5.3.1 TMACS Operators . . . . . . . . . . . . . . . . . . 10

5.3.2 Aging Waste Operators ........... . 10

5.3.3 Mitigation Pump Operators ........... 10

5.3.4 204-AR Building Operators ............. 11

5.3.5 Drywell Operators ............... 11

5.3.6 Routines Operators ............... 11

5.3.7 Field Crew Operators ............. 12

5.3.8 Saltwell Operators ............ 12

5.3.9 TWRS Waste Retrieval ............. 12

5.3.10 Field Sampling 0perators ............ 13

5.3.11 Core Sampling Operators ............. 13

5.3.11.1 Ground Crew Operator .......... 13

5.3.11.2 Push Mode Operator ... . . . . . . . 13

5.3.11.3 Rotary Mode Operator . . . . . . . . . 14

5.3.12 Cask/Sample Truck Operators: .......... 14

5.3.12A Characterization Project Routines ..... 14

5.3.13 Solid Waste Project - Waste Operations Truck . . . . . 14
Operator . . . . . . . . .

5.3.14 Sol id Waste Project - Waste Operations . . . . . . . 15

5.3.15 Solid Waste Project - Waste Operations Container
Document System Operators . . . 15

5.3.16 Sol id Waste Project - Waste Operations
Surveillance/Inspection Operators ......... . 15

5.4 General Manager . . . . . . . . . . . . . . . 16

5.4.1 TWRS Environmental Compliance Officer ...... 16

5.4.2 TWRS Operations Shift Managers and Operations

Engineer .............. . . 17

5.4.3 TWRS Operations Support Managers ........ . 17

5.4.4 TWRS Qual ified Person-In-Charge (PIC) ....... 18

5.4.5 Generator Services Operations Manager . . . . . . 18 
5.4.6 Generator Services 0perations Person-In Charge (PIC) 18

5.4.7 TWRS Hazardous Material Specialist....... 19

5.5 General Shipper .................... . 20

5.6 Waste Designator . . . . . . . . . . . . . . . 20

6.0 TRAINING CONTENT, FREqUENCY, AND TECHNIQUES . . . . . . . . . . . 20

6.1 Relevance of Training to Job Positions . . . . . . . . . . . 21

6.2 Training to Emergency Response ............... . 21

6.3 Waste Management Orientation ................ . . 22

6.4 Waste Management Awareness . . . . . . . . . . . . . . . . 22

6.5 Waste Management Advanced . . . . . . . . . . . . . . . . . 22

6.6 Waste Management Administration . . . . . . . . . . . . . . 23

6.7 Certification Training ................ . 23

6.8 Subcontractor Training and Visitor Training ........ 23

\section{List of Tables}

Table 1. Worker Categories . . . . . . . . . . . . . . . . . 5

Table 2. DOE-RL Program Area Descriptions . . . . . . . . . . . . . . . 6

Table 3. Certifications For Advanced General Workers (Nuclear Chemical Operators) Associated With TWRS TSD's . . . . . . . 9

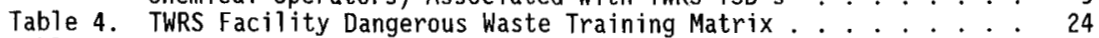

Table 5. TWRS Dangerous Waste Job-Specific Training Requirements

For Advanced General Workers (Nuclear Chemical Operators) . . . 25

Table 6. TWRS Dangerous Waste Job-Specific Training Requirements

For Managers And Engineers . . . . . . . . . . . . . 26

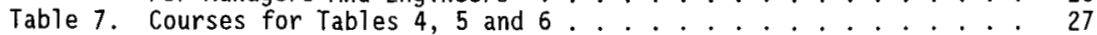

\section{List of Appendices}

Appendix A Training Course Descriptions . . . . . . . . . . . . . . . . A - i Appendix B Dangerous Waste Training Requirements Listed By Employee Job Position and Name (Examples)........... B - i 


\section{Acronyms}

ACES Access Control Entry System

BED Building Emergency Director

CASS - Computer Automated Sumvi7lance-System-

CFR Code of Federal Regulations

CPO Characterization Project Operations

DOT Department of Transportation

DST Double-Shell Tank

ECO Environmental Compliance officer

Ecology Washington State Department of Ecology

EPA Environmental Protection Agency

FDNW Fluor Daniel Northwest

GSO Generator Services Operations

IPT In-Plant-Training

JPM Job Performance Measure

LMHC Lockheed Martin Hanford Corporation

LOW Liquid Observation Wells

OE Operations Engineer

OJT On-The-Job Training

PIC Person-In-Charge

RCRA Resource Conservation \& Recovery Act

SST Single-She1l Tank

TMACS Tank Monitoring and Control System

TSD Treatment, Storage or Disposal Facility

TWRS Tank Waste Remediation System

WAC Washington Administrative Code

WMH Waste Management Federat Services of Hanford, Inc. 


\subsection{PURPOSE}

This document outlines the dangerous waste training program developed and implemented for all Treatment, Storage, and Disposal (TSD) Units operated by Lockheed Martin Hanford Corporation (LMHC) Tank Waste Remediation System (TWRS) in the Hanford 200 East, 200 West and 600 Areas and the <90 Day Accumulation Area at 209E. Operating TSD Units operated by TWRS are: the Double-Shell Tank (DST) System (including 204-AR Waste Transfer Building), the 600 Area Purgewater Storage and the Effluent Treatment Facility (Operated by Waste Management Federal Services of Hanford, Inc.). TSD Units undergoing closure are: the Single-Shell Tank (SST) System, 207-A South Retention Basin, and the 216-B-63 Trench.

The program is designed in compliance with the requirements of Washington Administrative Code (WAC) 173-303-330 and Title 40 Code of Federal Regulations (CFR) 265.16 for the development of a written dangerous waste training program and the Hanford Facility Permit. Training requirements were determined by an assessment of employee duties and responsibilities.

The TWRS training program is designed to prepare employees to operate and maintain the Tank Farms in a safe, effective, efficient, and environmentally sound manner. In addition to preparing employees to operate and maintain the Tank Farms under normal conditions, the training program ensures that employees are prepared to respond in a prompt and effective manner should abnormal or emergency conditions occur. Emergency response training is consistent with emergency responses outlined in the following Building Emergency Plans: HNF-IP-0263-TF and HNF-IP-0263-ETF.

\subsection{RESPONSIBILITIES}

The manager of each TWRS waste management unit has overall responsibility for all training at the TWRS units under their control. However, no one individual is designated as training director for the dangerous waste training program. The position is shared among TWRS training, and support

organizations. Each Tank Farm can access training resources and experts from many different areas on hazardous material, dangerous waste management, and safety rather than rely on the knowledge of one person. This shared responsibility ensures that the identification of appropriate training requirements and that the training program meets all applicable dangerous waste requirements.

2.1 TWRS Responsibilities. Each TWRS Unit Project manager has the following responsibilities related to training:

- Determine training requirements and training compliance for all Hanford Facility personne], subcontractors and visitors who obtain access or work within TWRS Units

- Request and/or conduct training

- Submit training completion records to TWRS Training Records.

- Identify training requirements to contractors working in or around TWRS Units. 
2.2 Training Organization Responsibilities. The Managers of Training Organizations have the following responsibilities:

- Ensure instructors have satisfactory instructional skills and are technically knowledgeable through: current qualification/ certification, or specialized training, or license/certificate, or degreed in the technical area, or other appropriate training or experience (see also D0E/RL-91-28 Chapter 8.0)

- Conduct informal job analysis and identify training commensurate with personnel duties and responsibilities

- Design and develop training programs

- Develop and instruct training courses

- Develop and maintain On-The-Job training requirements

- Operate and maintain the centralized Computerized Training Record System (CTRS) files

- Maintain the TWRS Training Records

- Process training completion records received into the CTRS System.

2.3 Environmental Organization Responsibilities. The Environmental Organization has the following responsibilities:

- Consult with training organizations and TWRS in the development and reevaluation of current training programs

- Assist TWRS Project Managers in determining training requirements and RCRA compliance for personnel

- Maintain current knowledge of RCRA training requirements pertaining to Hanford Facility Personnel.

2.4 Fluor Daniel Northwest (FDNW) and Waste Management Federal Services of Hanford, Inc. (WMH) Responsibilities. FDNW and WMH, whose personnel are classified as Hanford Facility Personnel, have the following responsibilities:

- Ensure that FDNW and WMH employees are trained to meet TWRS training requirements

- Maintain FDNW and WMH employees training records and provide them if requested by TWRS.

\subsection{IMPLEMENTATION OF TRAINING PROGRAM}

The TWRS Dangerous Waste training program is implemented. Incumbent personnel will complete new requirements within six months of the requirements being identified. Training of new employees is completed within the first six months of assignment. Training for personnel assigned to new positions is completed within six months of reassignment. Personnel who have not completed training are permitted to work at TWRS only under the supervision of a trained 
employee. TWRS operations management is responsible for ensuring that all personnel are trained and that required qualifications are maintained.

\subsection{Identification of Training}

The required training is specified by the employee's specific job duties as determined by a management assessment or job analysis. The required training identified in Tables 4,5 , and 6 is based on worker categories and job titles described in Sections 4.0 and 5.0.

\subsection{Conduct of Training}

Training is provided through classroom instruction, On-the-Job Training (OJT), In-Plant Training (IPT), Computer-based training, and selfstudy. Training is instructed and/or developed by personnel knowledgeable in dangerous waste management procedures.

Following initial training, employees are required to have annual refresher training. Employees requiring qualification are required to recertify annually or biennially, as stated in the program description for that job.

\subsection{Evaluation of Training}

TWRS management reevaluates TWRS training program courses at least every two years to ensure that dangerous waste training requirements continue to be met. Revisions to the TWRS training program are based on facility or system modifications, procedure changes, DOE Orders, Federal and State regulatory requirements, industry operating experience and personnel performance evaluations.

\subsection{Documentation of Training}

Copies of the training record files for TWRS dangerous waste management employees are stored at TWRS Training and the originals are sent to the Hanford Training Center Records Department. A computerized copy is available at each of the Tank Farms for verification of training, qualification, or certification for TWRS waste management. Training record copies, summaries for support organization employees and former employees (date of last worked at TWRS), are kept and stored at the Hanford Training Center for three months. After three months, the training records are signed and dated and then transferred to the Records Holding Area. Once received at the Records Holding Area, the records are scanned and then held there for approximately one year. After approximately one year, the original training records are archived and sent to the Permanent Records Storage at the Federal Depository in Renton, Washington. The retention period there is 75 years. 


\subsection{DANGEROUS WASTE WORKER CATEGORIES}

Employee duties at TWRS are categorized within six worker categories. In the event personnel duties and responsibilities overlap between categories, the employee will complete the training requirements for each category. These categories are:

1. A11 Employees

2. General Worker

3. Advanced General Worker

4. General Manager

5. General Shipper

6. Waste Designator

The duties corresponding to these categories are divided between "generator" and "TSD Unit-specific" job duties, each requiring varying degrees of dangerous waste management training. The description of job duties for each category can be matched to individual Job Titles or Job Positions commonly employed at the Hanford Facility. A description of the duties associated with each worker category is contained in Table 1. A description of dangerous waste training is contained in Table 2. Table 4 shows which programs are applicable for each worker category. 
Table 1. Worker Categories

\begin{tabular}{|c|c|c|}
\hline $\begin{array}{l}\text { WORKER } \\
\text { CATEGORIES }\end{array}$ & $\begin{array}{l}\text { GENERATOR } \\
\text { JOB DUTIES }\end{array}$ & $\begin{array}{l}\text { TWRS UNIT SPECIFIC } \\
\text { JOB DUTIES }\end{array}$ \\
\hline ALL EMPLOYEES & $\begin{array}{l}\text { Is not categorized as a General } \\
\text { Worker, Advanced General Worker, } \\
\text { General Manager, General Shipper, or } \\
\text { Waste Designator. Will not manage } \\
\text { waste in accumulation containers on } \\
\text { the Hanford Facility. Responsible to } \\
\text { report spills and releases that they } \\
\text { discover. Must respond to specific } \\
\text { incidents which may occur. }\end{array}$ & $\begin{array}{l}\text { Duties are the same as for generator } \\
\text { job duties for all employees. }\end{array}$ \\
\hline GENERAL WORKER & $\begin{array}{l}\text { Generates dangerous waste and places } \\
\text { waste into appropriate containers. } \\
\text { Waste management activities are } \\
\text { overseen by person-in-charge or other } \\
\text { TWRS unit personnel. Immediately } \\
\text { evacuate incident area and reports } \\
\text { incident to appropriate personnel. }\end{array}$ & $\begin{array}{l}\text { TWRS unit specific duties might } \\
\text { include repair, replacenent, } \\
\text { cal ibration, modification, or any } \\
\text { other similar activity on TWRS unit } \\
\text { systems. Work performed is either } \\
\text { supervised by qual ified TWRS personnel } \\
\text { or is adequately addressed through } \\
\text { organized pre-job briefing before } \\
\text { commencing work. Evacuate the TWRS } \\
\text { unit during emergencies and notifies } \\
\text { appropriate personnel. }\end{array}$ \\
\hline $\begin{array}{l}\text { ADVANCED } \\
\text { GENERAL WORKER }\end{array}$ & $\begin{array}{l}\text { Duties exceed those of General } \\
\text { Workers for container management. } \\
\text { Inspects, marks, inventories, and } \\
\text { samples containers of dangerous } \\
\text { waste. Responds to spills and } \\
\text { releases according to approved } \\
\text { procedures. Performs daily } \\
\text { inspections or surveillances on tank } \\
\text { systems. }\end{array}$ & $\begin{array}{l}\text { TWRS unit specific duties include the } \\
\text { control, operation, manipulation, } \\
\text { sampl ing, transfer or recording of } \\
\text { dangerous waste within containers, } \\
\text { tanks or waste process systems. } \\
\text { Includes abnormal operational } \\
\text { responses to maintain TWRS units } \\
\text { within operational parameters. } \\
\text { Implements emergency procedures and } \\
\text { responds to spills according to } \\
\text { approved procedures. }\end{array}$ \\
\hline GENERAL MANAGER & $\begin{array}{l}\text { Someone who can act as the } \\
\text { Environmental Compl iance officer, } \\
\text { Hazardous Material Special ist, or } \\
\text { directs Advanced General Workers in } \\
\text { dangerous waste management } \\
\text { activities. Responsible for the } \\
\text { accountability and directing of } \\
\text { employees during dangerous waste } \\
\text { emergency events. }\end{array}$ & $\begin{array}{l}\text { Duties are the same for generator job } \\
\text { duties for Advanced General Worker. }\end{array}$ \\
\hline GENERAL SHIPPER & $\begin{array}{l}\text { Signs paperwork relating to the } \\
\text { movement of dangerous waste } \\
\text { containers on roadways in compliance } \\
\text { with applicable requirements. } \\
\text { Directs General and Advanced General } \\
\text { workers in transportation activities. }\end{array}$ & $\begin{array}{l}\text { Duties are the same for generator job } \\
\text { duties for General shipper. }\end{array}$ \\
\hline WASTE DESIGNATOR & $\begin{array}{l}\text { Performs or completes waste } \\
\text { designations }\end{array}$ & $\begin{array}{l}\text { Duties are the same for generator job } \\
\text { duties for Waste Designator. }\end{array}$ \\
\hline
\end{tabular}


Table 2. DOE-RL Program Area Descriptions

\begin{tabular}{|c|c|}
\hline Program & Descriptions \\
\hline $\begin{array}{l}\text { Waste Management } \\
\text { Orientation }\end{array}$ & $\begin{array}{l}\text { Training in this program sub-area involves emergency responses, identifying contacts } \\
\text { for personnel to obtain dangerous waste management information, and waste minimization } \\
\text { concepts. Training also includes familiarization of the Hanford Facility Contingency } \\
\text { Plan (DOE/RL-93-75). }\end{array}$ \\
\hline $\begin{array}{l}\text { Unit/Bldg } \\
\text { Orientation }\end{array}$ & $\begin{array}{l}\text { This program sub-area provides unit/building specific information on the hazards in } \\
\text { the immediate and surrounding work environments. This training will ensure personnel } \\
\text { are informed about potential emergency at a unit/building to which access is desired. }\end{array}$ \\
\hline $\begin{array}{l}\text { Waste Management } \\
\text { Awareness }\end{array}$ & $\begin{array}{l}\text { The sub-area in this program addresses the generation of waste, segregating the waste, } \\
\text { and placing the waste into pre-approved containers. The training provides a } \\
\text { discussion on what the initial accumulation container is titled and the management } \\
\text { requirements that pertain, proper responses to incidents pertaining to the initial } \\
\text { accumulation containers, proper responses to dealing with waste of unknown origins, } \\
\text { and proper responses to questions posed by a regulatory agency inspector concerning } \\
\text { these elements. General safe practices for handling and storing dangerous } \\
\text { waste/materials are addressed. }\end{array}$ \\
\hline $\begin{array}{l}\text { Unit/Bldg } \\
\text { Awareness }\end{array}$ & $\begin{array}{l}\text { This program sub-area encompasses the job-specific or building-specific requirements } \\
\text { that supplement the information provided in waste management awareness general sub- } \\
\text { area. The training provides personnel at each unique unit/building with proper waste } \\
\text { handing and emergency procedures relevant to their responsibilities during normal } \\
\text { operations and emergencies. }\end{array}$ \\
\hline $\begin{array}{l}\text { Waste } \\
\text { Management } \\
\text { Advanced }\end{array}$ & $\begin{array}{l}\text { The training within this sub-area is for unit/building personnel who must ensure that } \\
\text { the waste management unit is operating in accordance with approved procedures and } \\
\text { applicable regulations. General advanced training is provided only for container } \\
\text { management. Training for other RCRA units such as tank systems, surface impoundnents, } \\
\text { landfills, etc., must be covered through the unit/building specific portion of the } \\
\text { advanced program. }\end{array}$ \\
\hline Unit/BIdg Advanced & $\begin{array}{l}\text { This sub-area provides specific information required to operate, control, and manage } \\
\text { processes and dangerous waste management operations. For container management, the } \\
\text { unit/building specific program supplements the information provided in the general } \\
\text { training within this program area. Considerations for this program involve container } \\
\text { management as well as all advanced program area training for other RCRA units such as } \\
\text { tank systems, surface impoundments, landfills, etc. This program can be met or } \\
\text { partialty met by the unit/job specific program area if operator and supervisor/manager } \\
\text { qualification programs must be administered. }\end{array}$ \\
\hline $\begin{array}{l}\text { Waste } \\
\text { Management } \\
\text { Administration }\end{array}$ & $\begin{array}{l}\text { This program area covers administrative aspects such as document preparation for plans } \\
\text { and procedures relating to envirormental reporting, waste minimization, and waste } \\
\text { management. It also covers sampling and analysis considerations to aid in the } \\
\text { development of sampling and analysis plans, waste analysis plans and waste } \\
\text { designations. }\end{array}$ \\
\hline $\begin{array}{l}\text { Unit/Job } \\
\text { Specific }\end{array}$ & $\begin{array}{l}\text { Training within this program area constitutes one of the tools used in developing a } \\
\text { compliant unit/building specific training program and is based on compliance with DoE } \\
\text { Order } 5480.20 \mathrm{~A} \text {. It is designed to provide additional information to ensure the safe } \\
\text { and efficient operation and maintenance of unit processes, and does not apply to all } \\
\text { unit/buildings on the Hanford Facility. Additionally, the training provides more } \\
\text { detailed information for the response to emergencies and abnormal events that could } \\
\text { occur. Not atl training within this program will be RCRA related. Some operator or } \\
\text { supervisor/manager qualification programs are not based on dangerous waste management. }\end{array}$ \\
\hline
\end{tabular}

NOTE :

Double line indicates split in program areas 


\subsection{JOB POSITIONS AND DESCRIPTIONS}

Each employee is assigned a job title (from salaried nonexempt or bargaining unit classifications) or position (from exempt classifications). Job or position descriptions include requisite skills, work experience, education, and other qualifications, and a list of duties and/or responsibilities for each job title or position. The work experience, education, and other qualifications required for each position are maintained by Human Resources. As a minimum, all employees require a high school diploma or equivalent. Personnel filling exempt, management or engineering positions normally require a college degree with 2 or more years of industry experience.

In the following sections, brief job titles and position descriptions of employees associated with dangerous waste management at TWR are 1isted within the appropriate worker category.

\subsection{A11 Employees}

Hanford Facility personnel included in this category are not categorized into one of the other five worker categories. Visitors and subcontractors included within this category are those personnel not categorized as General Workers and that require access to portions of the TWRS Facilities not accessible to the public. Personnel in this category will not perform duties or responsibilities associated with the management of waste in accumulation containers or with the critical system of the TWRS unit. All personnel have the responsibility to report spills and releases that they discover in addition to evacuation or take cover actions in response to specific incidents.

Most Hanford Facility personnel categorized as "Al1 Employees" are administrative personnel such as secretaries, clerks and support organizations who tour or provide oversight. Most visitors will be categorized as All Employees since visitors generally tour, provide oversight, or are brought on the Hanford Facility for interviews. Subcontractors who gain access to the TWRS Facilities to complete work in controlled areas, which does not involve the management of dangerous or mixed waste, will be categorized as All Employees.

\subsection{General Worker}

Hanford Facility personnel or subcontractors with waste management duties and responsibilities limited to the initial generation of waste and placing that waste into a pre-approved containers are classified as General Workers. These personnel could generate dangerous or mixed waste while working on a non-RCRA system (e.g., building maintenance) or on a TSD unit conducting maintenance or modification on critical or non-critical systems. The term "critical system" is defined in the Hanford Facility RCRA Permit. The work may be unsupervised or completed under the supervision of a Person-In-Charge (PIC) or unit/building personnel.

Hanford Facility personnel categorized as General Workers may be assigned duties and responsibilities for: (1) placing waste they generate into preapproved containers and filling out log sheets where applicable, (2) completing radiological surveys of dangerous or mixed waste, (3) the loading of packaged containers onto trucks or movement of containers where a spill or release may occur, and (4) responding to regulatory agency compliance inspectors questions about satellite accumulation area management practices. 
Personne 1 who function as General Workers may include, but are not 1 imited to, the following:

- Maintenance personnel

- Health physics technicians

- Subcontractor supervisors of general workers

- Transporters

- Contractor crafts

- Ecology personnel acquiring samples of dangerous or mixed waste

\subsection{Advanced General Worker}

Hanford Facility personnel are categorized as Advanced General Workers if their duties and responsibilities concerning dangerous or mixed waste exceed that of General Workers. Nuclear Chemical Operators are typically Advanced General Workers. Examples of these duties and responsibilities for container management can include: inspecting containers, applying advanced container markings and preparing container log sheets, completing waste inventories, sampling of waste, and responding to spills and releases according to approved procedures.

For TWRS RCRA TSD units, Hanford Facility personnel assigned duties and responsibilities associated with ensuring the compliant operation of that TSD unit will be categorized as Advanced General Workers. Their duties and responsibilities may include, but are not limited to: operators who conduct daily inspections on tank systems to ensure they are operating properly and operators who conduct daily inspections on tank system ancillary equipment that is not provided with secondary containment and receiving shipments of waste. In these cases, the operator must perform an evaluation whether the TSD unit is functioning properly and operating in compliance with WAC 173-303. These personnel typically have the responsibility to act and/or notify TWRS operations management when an incident occurs that requires immediate response, such as a leaking or deteriorating container, spill or release, or process upset. Table 3 lists which TSD facilities utilize the Advanced General Workers. The list of employees currently filling these positions is maintained by HNF-IP-0974. An example is provided in Appendix B-1. 


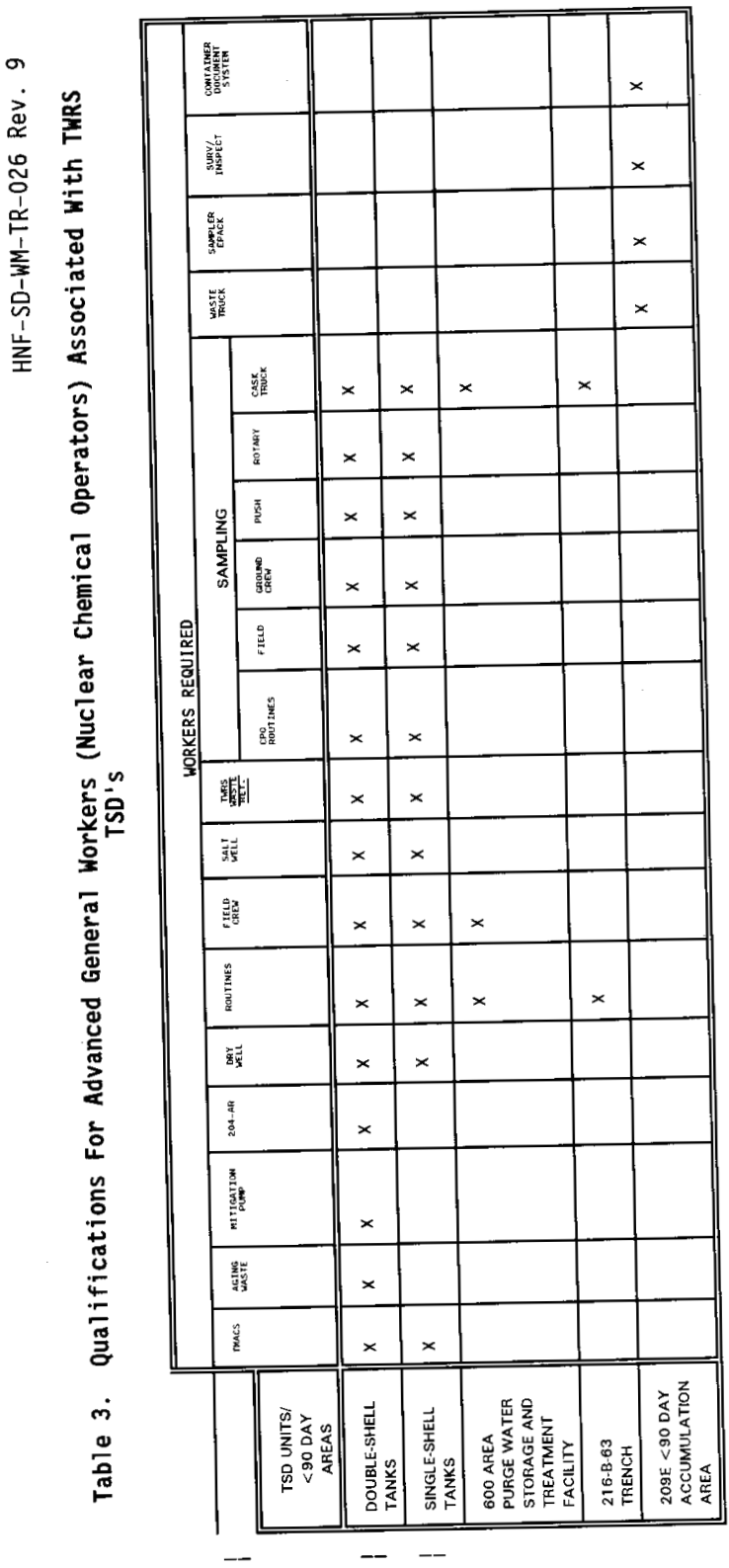

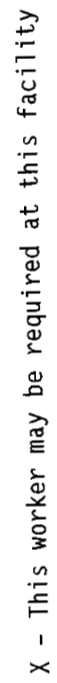


5.3.1 TMACS Operators. Responsibitities and duties include:

- Operate the CASSFTMACS Central FaciTity

- Review reports generated by EASS and the Tank Monitoring and Control System of CASS (TMACS)

- Inform supervisors of abnormal conditions in SSTs and DSTs reported by CASS OP TMACS.

5.3.2 Aging Waste Operators. Responsibilities and duties include:

- Perform Aging Waste Facilities work activities in accordance with current operating procedures

- Perform sampling as required by procedure

- Operate process equipment associated with the Aging Waste Facilities

- Provide surveillance of the Aging Waste Facilities for abnormal conditions

- Respond to alarms at the Aging Waste Facilities

- Respond to abnormal and/or emergency conditions according to established procedures

- Respond to dangerous waste leaks or spills

- Perform routine inspections of the Aging Waste Facilities (241-AY and 241-AZ Tank Farms).

5.3.3 Mitigation Pump Operators. Responsibilities and duties include:

- Perform mitigation pump work activities in accordance with current operating procedures

- Operate mitigation pump processes, systems, and equipment at the Tank Farms

- Conduct routine inspections

- Provide surveillance of the Tank Farms for abnormal conditions

- Respond to alarms at the Tank Farms

- Respond to abnormal and/or emergency conditions according to established procedures. 


\subsubsection{4-AR Building Operators. Responsibilities and duties} include:

- Perform 204-AR Building work activities in accordance with current operating procedures

- Operate processes, systems, and equipment at the 204-AR Building

- Perform sampling as required by procedure

- Conduct routine inspections

- Provide surveillance of the 204-AR Building for abnormal conditions

- Respond to alarms at the 204-AR Building

- Respond to abnormal and/or emergency conditions according to established procedures

- Respond to dangerous waste leaks or spills

- Transfer waste from tankers to DSTs

- Transfer waste from rail cars to DSTS

- Treat waste transferred to DSTs to maintain operating specifications.

5.3.5 Drywell operators. Responsibilities and duties include:

- Perform Drywell Van work activities in the Tank Farms in accordance with current operating procedures

- Perform In-Tank Photography and Video Taping in accordance with current operating procedures

- Operate the Drywell Van and support systems used to monitor Drywells, Liquid Observation Wells (LOW) and Laterals.

\subsubsection{Routines Operators. Responsibilities and duties include:}

- Perform Tank Farm work activities in accordance with current operating procedures

- Operate processes, systems, and equipment at the Tank Farms

- Perform sampling as required by procedure

- Conduct routine inspections

- Provide surveillance of the Tank Farms for abnormal conditions

- Respond to alarms at the Tank Farms

- Respond to abnormal and/or emergency conditions according to established procedures 
- Respond to dangerous waste leaks or spills

- Escort supporting crafts and visitors entering the Tank Farm areas as required.

5.3.7 Field Crew 0perators. Responsibilities and duties include:

- Perform Tank Farm work activities in accordance with current operating procedures

- Perform sampling as required by procedure

- Conduct routine inspections

- Respond to alarms at the Tank Farms

- Respond to abnormal and/or emergency conditions according to established procedures

- Respond to dangerous waste leaks or spills

- Perform waste transfer routing changes

- Perform pipeline pressure tests

- Perform equipment installation and removal

- Perform tank lancing operations.

5.3.8 Saltwell 0perators. Responsibilities and duties include:

- Operate the jet pumps to transfer waste from SSTs to DSTS

- Perform Saltwell work activities in accordance with current operating procedures, including data collection

- Perform sampling as required by procedure

- Conduct routine inspections of Saltwell systems

- Respond to and trouble shoot Saltwell alarms

- Respond to abnormal and/or emergency conditions according to established procedures

- Respond to dangerous waste leaks or spills.

5.3.9 TWRS Waste Retrieval. Responsibilities and duties include:

- Start-up, operate, and shutdown of the Sluicing System

- Operate the Data Acquisition System

- Operate the WRSS Raw Water System

- Know the BIO/TSR/LCO/AC's associated with STuicing 
- Wear an SCBA

- Start-up, operate, and shutdown the WRSS 296-C-006 HVAC System

- Respond to alarms and abnormal conditions

5.3.10 Field Sampling Operators. Responsibilities and duties include:

- Perform Tiquid and vapor sampling of SSTs and DSTs as required by procedure.

- Support laboratory personnel in the performance of sampling as required by procedure.

- Perform auger sampling of SSTS and DSTS as required by procedure.

- Perform Tank Farm work activities in accordance with current operating procedures

- Respond to abnormal and/or emergency conditions according to established procedures

- Respond to dangerous waste leaks or spills.

\subsubsection{Core Sampling Operators.}

\subsubsection{Ground Crew Operator Responsibilities and duties} include:

- Perform Tank Farm work activities in accordance with current operating procedures

- Respond to abnormal and/or emergency conditions according to established procedures

- Respond to dangerous waste leaks or spil1s

- Perform ground activities in support of the core sampling trucks and systems, either Rotary Mode or Push Mode, as required by procedure, to take samples of the waste tank core layers.

\subsubsection{Push Mode Operator: Responsibilities and duties include:}

- Perform Tank Farm work activities in accordance with current operating procedures

- Respond to abnormal and/or emergency conditions according to established procedures

- Respond to dangerous waste leaks or spills

- Operate the core sampling trucks and systems in Push Mode, as required by procedure, to take samples of the waste tank core layers. 


\subsubsection{Rotary Mode Operator: Responsibilities and duties} include:

- Perform Tank Farm work activities in accordance with current operating procedures

- Respond to abnormal and/or emergency conditions according to establi shed procedures

- Respond to dangerous waste leaks or spills

- Operate the core sampling trucks and systems in Rotary Mode, as required by procedure, to take samples of the waste tank core layers.

\subsubsection{Cask/Sample Truck Operators: Responsibilities and duties include:}

- Perform Cask/Sample truck work activities in accordance with current operating procedures

- Pick-up and transport samples to the laboratories

- Respond to accidents involving Cask/Sample truck.

5.3.12A Characterization Project Routines Operator: Responsibilities and duties include:

- Perform Tank Farm work activities in accordance with current operating procedures

- Respond to abnormal and/or emergency conditions according to establi shed procedures

- Respond to dangerous waste leaks or spills

- Perform In-Tank Photography and Video Taping in accordance with current operating procedures

- Perform prepatory work for sampling activities in accordance with current operating procedures.

\subsubsection{Solid Waste Project - Waste Operations Truck Operators.} Responsibilities and duties include:

- Ensure that vehicles transporting dangerous wastes are up to date on maintenance schedules

- Prepare containers to receive mixed and dangerous waste

- Deliver and collect waste containers from Satellite Accumulation Areas and waste generators

- Setup Satellite Accumulation Areas

- Unload trucks at the $<90$-day accumulation area 
- Ensure that trucks transporting dangerous waste are placarded properly

- Ensure that the waste has been properly secured in the transportation vehicles.

\subsubsection{Solid Waste Project - Waste Operations Sampling/ Repacking} Operators. Responsibilities and duties include:

- Package and label dangerous waste for shipment from the $<90$ day accumulation area

- Perform sampling as required by procedure at the $<90$ day accumulation area

- Support laboratory personnel in the performance of sampling as required by procedure at the $<90$ day accumulation area

- Prepare containers to receive mixed and dangerous waste

- Escort supporting crafts and visitors entering the <90-day accumulation area as required

- Receive, segregate, sort, inventory, store, and stage dangerous waste

- Operate processes, systems, and equipment at the <90-day accumulation area

- Respond to alarms at the <90-day accumulation area

- Respond to abnormal and/or emergency conditions according to established procedures

- Respond to dangerous waste leaks or spills.

\subsubsection{Solid Waste Project - Waste Operations Container Document} System Operators. Responsibilities and duties include:

- Maintain tracking records for dangerous and mixed waste containers

- Complete shipping documentation for dangerous and mixed waste containers

- Develop container tracking folders.

\subsubsection{Solid Waste Project - Waste Operations Surveillance/Inspection} operators. Responsibilities and duties include:

- Perform <90-day accumulation area work activities in accordance with current operating procedures

- Escort supporting crafts and visitors entering the <90-day accumulation area as required

- Receive, segregate, sort, inventory, store, and stage dangerous waste 
- Operate processes, systems, and equipment at the <90-day accumulation area

- Conduct routine inspections

- Package and 1abel dangerous waste for shipment

- Provide surveillance of the $<90$-day accumulation area for abnormal conditions

- Assist truck drivers in loading and unloading trucks at the <90-day accumulation area

- Ensure that trucks transporting dangerous waste are placarded properly

- Respond to alarms at the <90-day accumulation area

- Respond to abnormal and/or emergency conditions according to established procedures

- Respond to dangerous waste leaks or spills.

\subsection{General Manager}

Various types of managers are included in this position. In addition, TWRS personnel may be categorized as General Managers if they direct General Worker or Advanced General Worker activities. Managers and those who direct General Workers and Advanced General Workers have many similar duties and responsibilities relating to dangerous or mixed waste management and are required to take the same courses.

The following managers are included within this position:

(1) TWRS Environmental Compliance officer

(2) TWRS Operations Shift Managers and Operations Engineers

(3) TWRS Operations Support Managers

(4) TWRS Qualified Person-In-Charge (PIC)

(5) Generator Services Operations Manager

(6) Generator Services Operations Person-In-Charge (PIC)

(7) TWRS Hazardous Material Specialist

The 1 ist of employees currently filling these positions is maintained by HNF-IP-0974. Examples are provided in Appendix B-2 and B-3.

5.4.1 TWRS Environmental Compliance Officer. Responsibilities of the Environmental Compliance officer include the following:

- Provide support to TWRS unit management to ensure compliance with the applicable environmental compliance requirements as identified in this manual, environmental permits, the Hanford Federal Facility Agreement and Consent Order, HNF-CM-7-5, Tank Farm S/RIDS and other compliance orders

- Ensure that TWRS unit management is aware of the unit's environmental compliance status and the unit's environmental compliance activities 
- Understand and be able to explain the TWRS unit's environmental compliance status with all applicable environmental requirements

- Advise the TWRS unit management of new environmental requirements and policies, the associated impacts, and recommended implementation mechanisms to ensure compliance.

\subsubsection{TWRS Operations Shift Managers and Operations Engineers. Responsibilities of the TWRS Operations Shift Managers Operations Engineers include the following:}

- Supervise, coordinate, and direct the activities in the Tank Farms

- Ensure that TWRS operations are conducted in accordance with established operating procedures and policies, U.S. Department of Energy Orders, and Federal and State regulations

- Supervise and coordinate the receipt, storage, transfer, and reprocessing of dangerous waste

- Ensure compliance with TWRS operating limits and specifications

- Conduct pre-job safety and planning meetings with personnel involved with Tank Farms operations as applicable

- Maintain operating records

- Revise and review TWRS operating procedures as applicable

- Recognize abnormal conditions and take appropriate action

- Respond to abnormal and/or emergency conditions according to established procedures

- Notify TWRS management of any unplanned releases to the environment

- Serve as the building emergency director (BED), the staging area manager or designated alternate BED, as assigned

- Perform the duties of the building emergency director, as assigned, for the Tank Farms during emergencies.

5.4.3 TWRS Operations Support Managers. Line Management within the TWRS Operations Organization provides support as applicable to ensure the safe, effective, efficient, and environmentally acceptable operation of TWRS facilities and systems. This operation is in accordance with applicable dangerous waste management procedures, U.S. Department of Energy Directives, applicable management policies, and Federal and State regulations.

Responsibilities of the TWRS support organizations management and technical support personnel include, but are not limited to, the following functions:

- Maintenance

- Production Control

- Recovery Support

- Isolation/Stabilization

- Waste Retrieval 
- Vapor, Liquid and Core Sampling.

5.4.4 TWRS Qualified Person-In-Charge (PIC). Responsibilities and duties include:

- Coordinate and direct the activities of Advanced General Workers in the completion of field activities

- Review procedures to assure that they are adequate to perform and control the tasks

- Ensure work is performed in compliance with environmental regulations and permits through adherence to procedures and control manuals.

\subsubsection{Solid Waste Project - Waste Operations Manager. Responsibilities and duties include:}

- Supervise, coordinate, and direct the activities of Generator Services Operations Team Leaders

- Maintain control over <90-day accumulation area operations in accordance with established operating procedures and policies, U.S. Department of Energy Orders, and State, and Federal regulations

- Direct, control, and coordinate the recejpt, storage, transfer, and processing of dangerous waste

- Ensure <90-day accumulation area operations are conducted according to established procedures

- Ensure compliance with $<90$-day accumulation area operating limits and specifications

- Ensure that job safety and planning meetings are conducted, as applicable, with personnel involved with the <90-day accumulation area operations

- Ensure that regulatory records are maintained

- Develop, revise, and review $<90$-day accumulation area operating procedures as applicable

- Respond to and provide remedial guidance and decisions for operational anomalies, abnormal conditions, and equipment malfunctions

- Respond to abnormal and/or emergency conditions according to established procedures

- Coordinate the recovery from unplanned releases to the environment and other emergency conditions.

\subsubsection{Solid Waste Project - Waste Operations Person-In-Charge (PIC).} Responsibilities and duties include:

- Supervise, coordinate, and direct the activities of the Generator Services Operators 
- Ensure that <90-day accumulation area operations are in accordance with operating procedures and policies, U.S. Department of Energy Orders, State, and Federal regulations

- Supervise and coordinate the receipt, storage, transfer, and reprocessing of dangerous waste

- Conduct <90-day accumutation area operations according to established procedures

- Ensure compliance with $<90$-day accumulation area operating limits and specifications

- Conduct pre-job safety and planning meetings (Job Specific Training) with personnel involved with $<90$-day accumulation area operations as applicable

- Maintain regulatory records

- Revise and review <90-day accumulation area operating procedures as applicable

- Recognize abnormal conditions and take appropriate actions

- Respond to abnormal or emergency conditions according to established procedures

- Notify <90-day accumulation area management of any unplanned releases

- Ensure that vehicles transporting dangerous wastes are current on maintenance schedules

- Ensure that waste has been properly secured in transportation vehicles.

5.4.7 TWRS Hazardous Material Specialist. Responsibilities and duties inc1ude:

- Create and maintain satellite accumulation areas for maintenance of waste generated in non-radiologically controlled areas in compliance with applicable requirements

- Interface with other organizations as needed to ensure proper disposal of wastes

- Prepare and maintain documents required by Federal and State regulations and $L M H C$ policies

- Ensure non-regulated alternatives are used whenever possible by reviewing purchase requisitions for chemical products

- Provide review and waste disposition instructions on the waste planning checklist as required

- Recognize abnormal conditions and take appropriate action 
- Respond to abnormal or emergency conditions according to established procedures

- Ensure that the waste has been properly secured in the transportation vehicles.

\subsection{General Shipper}

Personnel who sign waste movement documentation for both onsite and off-site shipments of dangerous or mixed waste on roadways are categorized as General Shippers in the RCRA training program. There is no distinction within this category based upon where a dangerous or mixed waste movement will initiate, terminate, or which road the movement will travel along. The list of employees currently filling this position is maintained by HNF-IP-0974. An example is provided in Appendix B-4.

\subsection{Waste Designator}

Personnel who perform and/or complete waste designations at TWRS waste management units are categorized as a Waste Designator. The list of employees currently filling this position is maintained by HNF-IP-0974. An example is provided in Appendix B-4.

\subsection{TRAINING CONTENT, FREQUENCY, AND TECHNIQUES}

This section provides an overview of dangerous waste management and jobspecific training provided to employees in job titles and positions discussed in the previous sections. In addition to TWRS normal operating conditions, employees are trained on emergency equipment, systems, and procedures to include the following, where applicable:

- Procedures for using, inspecting, repairing and replacing TWRS emergency and monitoring equipment

- Automatic or manual dangerous waste feed cut-off systems

- Communications and alarm systems

- Response to fires and explosions

- Response to dangerous waste contamination incidents and spills

- Shutdown of operations.

The training program uses existing courses with content ranging from general to specific dangerous waste training material. Initial and continuing training program requirements are 1 isted in Table 4 for each worker category. Appendix A-1 contains a brief description of the training courses for this program, including course title, course description, target audience, instructional delivery, evaluation method, length of course, and frequency of retraining.

The TWRS-specific and job-specific qualifications and/or certifications are maintained according to contractual and regulatory requirements. Courses are provided through classroom instruction, on-the-job training, in-planttraining, self-study, and computer-based training and addresses the TWRS 
management procedures, U.S. Department of Energy directives, applicable management policies, and Federal and State regulatory requirements. The training includes instruction on the implementation of the Tank Farms contingency plan (Building Emergency Plan) and use of emergency and monitoring equipment. The TWRS nuclear operators and operations shift managers are certified for assigned jobs through a performance-based training process.

The TWRS support organizations employees are also required to complete identified TWRS training applicable to their involvement with dangerous waste management. The TWRS support organizations management is responsible for identifying individual employee training requirements in accordance with this plan and for ensuring that training requirements are met.

The TWRS initial and continuing training program job-specific course requirements relating to dangerous waste management are 1 isted in Tables 5 and 6 . Appendix A-2 contains a brief description of the training courses for this program, including course title, course description, target audience, instructional delivery, evaluation method, length of course, and frequency of retraining.

\subsection{Relevance of Training to Job Positions}

The dangerous waste training program for TWRS employees was developed after reviewing U.S. Department of Energy directives, Federal and State regulations, and the completion of a job analysis for management-selected job positions. Tasks performed by employees were identified and evaluated to determine training requirements. In addition, training needs are evaluated continually in relation to current U.S. Department of Energy directives and Federal and state regulations.

Qualification for Operations Shift Managers, Nuclear 0perators and Nuclear Chemical Dperators are required by U.S. Department of Energy Order 5480.20A. Qualification for General Shippers is required by LMHC policy. To become certified, an employee must successfully complete classroom training, self-study, and on-the-job training, as applicable. Classroom instruction and/or self-study is designed to provide qualification candidates with the fundamental knowledge required to work safely at TWRS.

The TWRS Dangerous Waste training program outlined here ensures that all personnel entering the Tank Farms are trained properly to perform the job duties pertinent to the handling, treatment, storage, and/or disposal of dangerous waste.

TWRS employees and support organization employees also receive additional training in accordance with other regulations such as 29 CFR 1910.120, "Hazardous Waste Operations and Emergency Response" and 29 CFR 1910.1200, "Hazard Communication Program," and the U.S. Department of Energy directives and management policies including "Environmental Regulations at Hanford". These courses are not discussed in this training plan.

\subsection{Training to Emergency Response}

Federal and State regulations require that employees be able to respond effectively to emergencies and that employees be familiar with emergency procedures, emergency equipment, and emergency systems. Specific topics required by Federal and State dangerous waste regulations listed in Section 
6.0 are addressed throughout the Dangerous Waste training program and are included in the following training:

- New Employee Safety Orientation

- Hanford General Employee Training

- Tank Farms Facility Orientation

- Generator Hazards Safety Training

- Facility Emergency and Hazard Information Checklist

- TWRS Nuclear Operator and Manager qualification training

- Building Emergency Director training.

\subsection{Waste Management Orientation}

A11 employees are required to complete Waste Management 0rientation (see Table 4) training, which includes site emergency response training. The training at this level involves a basic introduction to dangerous waste management. It addresses correct response to emergencies involving releases of materials to the environment. It includes a discussion of the "Hanford Facility" and permits for TSDs along with additional training requirements should employee dangerous waste management duties change.

Tank Farms orientation is provided for personnel who require access to a TWRS TSD Unit/Building. Training is conducted for the Tank Farms Emergency Signals and appropriate responses.

\subsection{Waste Management Awareness}

In addition to Waste Management Orientation, Waste Management Awareness (see Table 4) training is required for general workers, advanced general workers, general managers, and general shippers. The training at this level is commensurate with the duties of generating waste and placing into preapproved containers. The training addresses the identification, packaging, marking and labeling and proper handling of dangerous wastes including the regulatory requirements for accumulation and storage. Additionally, the training covers contingency plan requirements and worker response to smal1 spills, materials release reporting, and notifications. General safe practices for handling, storing and transporting dangerous waste materials are addressed.

Unit/Building-specific training is also provided. This portion of the training encompasses the job-specific or building-specific requirements that supplement the information provided in waste management awareness. The training provides employees with proper waste handling and emergency procedures relevant to their responsibilities during normal facility operations and emergencies.

\subsection{Waste Management Advanced}

In addition to Waste Management Orientation and Waste Management Awareness, general managers, general shippers, and Environmental Waste Operators must complete Waste Management Advanced (see Table 4) training. General managers complete training on environmental regulations and/or environmental compliance. The training includes information on potential legal liabilities, applicable Federal and State regulations, various reporting requirements, inspections/audits and record keeping. General shippers and Generator Services Operators complete containerized waste management training. 
The training is for facility personnel who properly select, package and prepare for shipment containers of dangerous wastes. This is a comprehensive container waste management training program and provides the necessary information regarding documentation, reporting, record keeping, and other information pertaining to administrative functions of dangerous waste management.

\subsection{Waste Management Administration}

Waste Management Administration is for general shippers, waste designators and those who must resolve problems and issues related to dangerous waste management. This training covers administration aspects of waste minimization, waste management, and record keeping for the Hanford Facility.

\subsection{Qualification Training}

In addition to Waste Management Orientation and Waste Management Awareness, nuclear operators and Operations Shift Managers complete specific courses in preparation for work assignments. Qualifications for job-specific work assignments have been developed in accordance with U.S. Department of Energy order 5480.20A. The training at this level is designed to provide indepth facility knowledge to ensure the safe and efficient operation of TWRS processes and operations. Additionally, qualification training provides detailed information for the response to emergencies and abnormal events which could occur within the unit. Once certified, employees are required to recertify biennially through continuing training classes, self study and completion of an examination.

\subsection{Subcontractor Training and Visitor Training.}

Subcontractor personnel and visitors at TWRS must complete the appropriate level of training determined by TWRS management according to their job duties.

Personnel who have completed training off-site are required to provide a certificate or other suitable evidence of training course(s) that meet the requirements of WAC 173-303 and this plan. The TWRS Project Manager must verify the acceptability of off-site training as commensurate with subcontractor personnel's anticipated TWRS job assignment and the training requirements 1 isted in Table 4.

TWRS Management is responsible for ensuring that subcontractor personnel and visitor medical surveillance requirements are met before granting access to the Tank Farms. TWRS management is responsible for ensuring that all the requirements for access to the Tank Farms are met. 


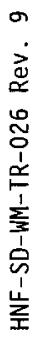

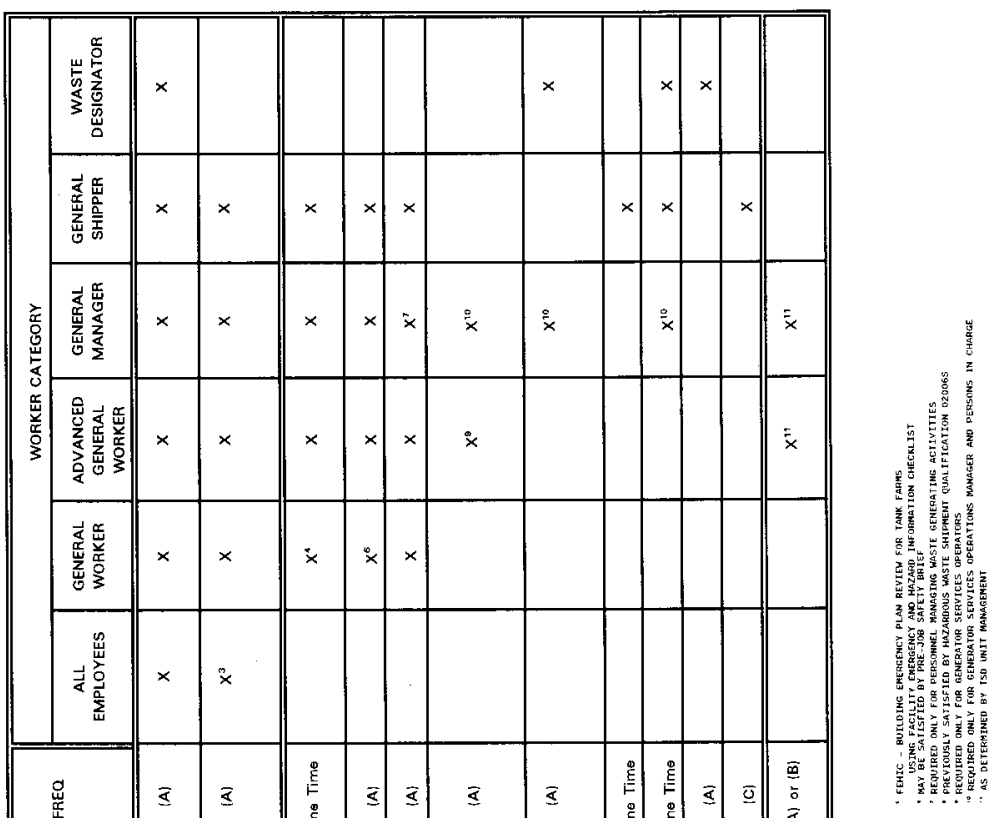




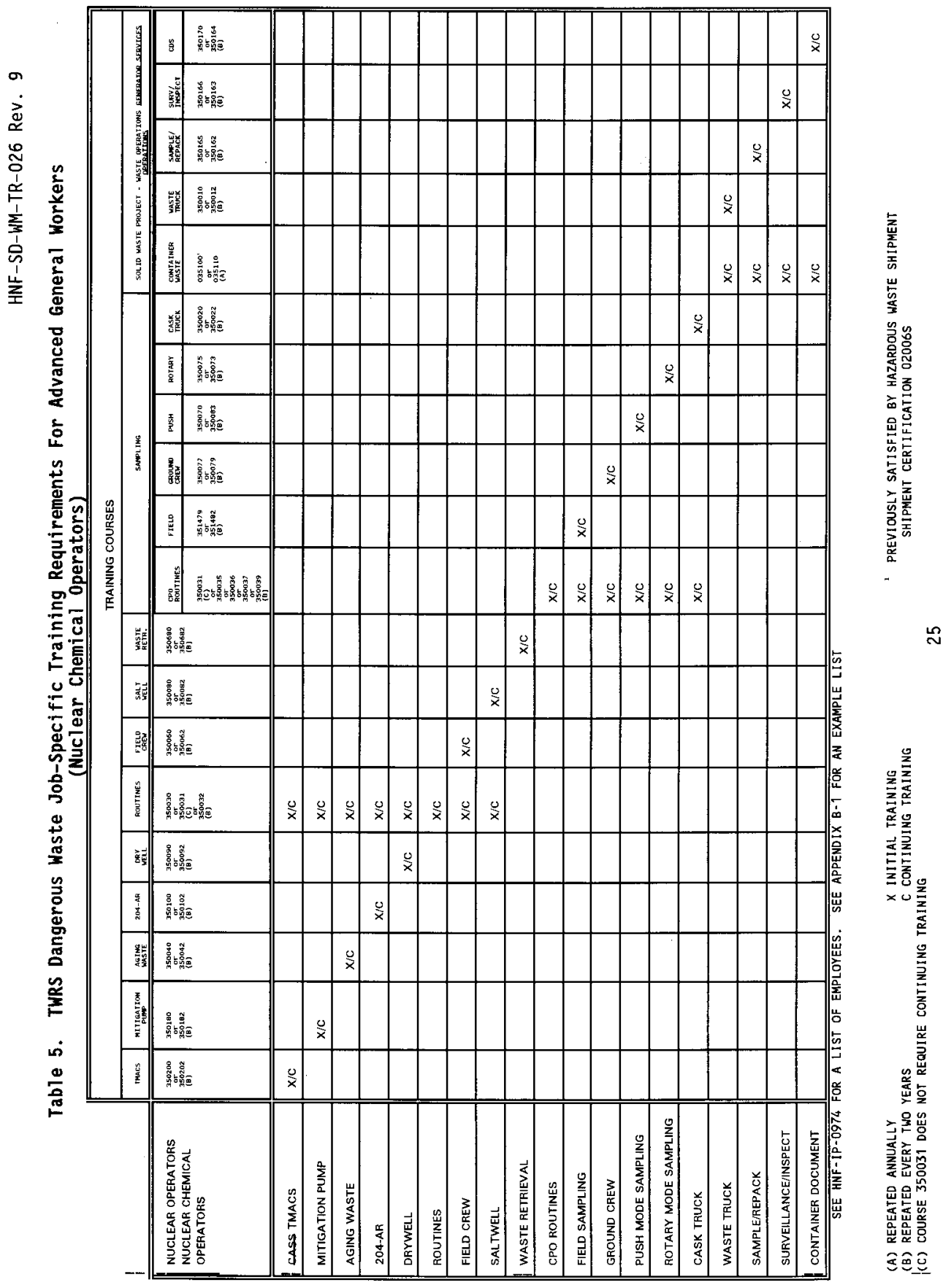




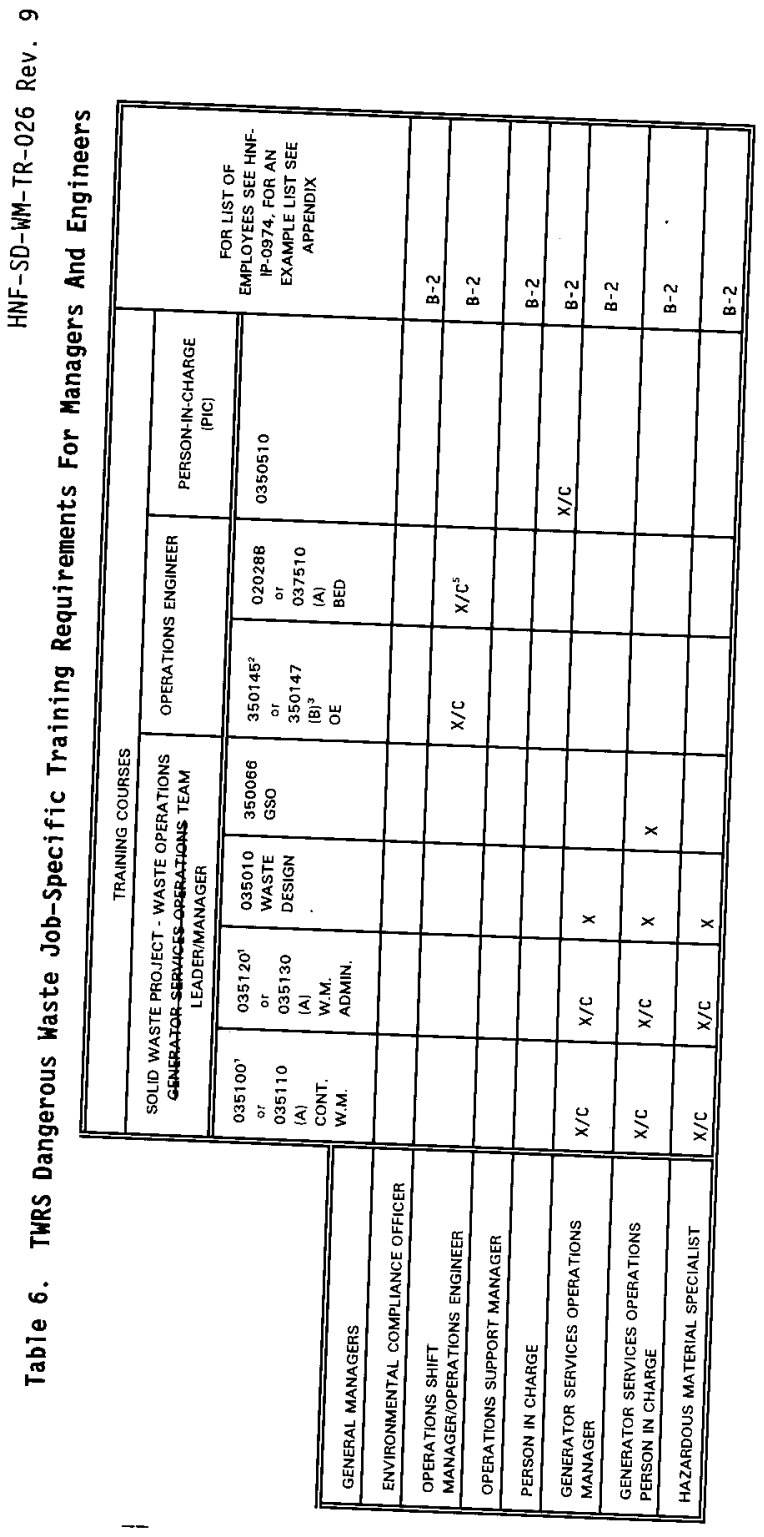


Table 7. Courses for Tables 4,5 and 6

\section{CURRENT COURSES DESCRIBED IN APPENDIX A}

000001

000090

$02006 \mathrm{G}$

020159

$02028 \mathrm{~B}$

035010

035012

035020

035100

035110

035120

035130

037510

$03 E 060$

350010

350020

350030

350031

350035

350037

350040

350060

350066

350070

350075

350077

350080

350090

350100

350145

350165

350166

350167

350180

350200

350510

350560

350680

350710

350760

351479

350012

350022

Hanford General Employee Training (HGET)

Visitor/Vendor Orientation

Waste Management Awareness

Hazardous Waste Shipper Qualification - Advanced Course 2

Building Emergency Director Training

Waste Designation

Waste Designation Qualification

Facility Waste Sampling and Analys is

Container Waste Management - Initial

Container Waste Management - Refresher

Waste Management Administrative - Initial

Waste Management Administrative - Refresher

Building Emergency Director/Building Warden - Requalification

Building Emergency Plan Review using the Facility Emergency and

Hazard Information Checklist for Tank Farms

Solid Waste Project - Waste Operations Truck

Operations - Initial Qualification

Cask/Sample Transport Truck Operations - Initial Qualification

Tank Farms Routine Operations - Initial Qualification

Tank Farms Routines Classroom

Characterization Project Routine Operations - Initial

Qualification

CPO Routines Revised Qualification (With In-Tank Video)

Tank Farms Aging Waste Operations - Initial Qualification

Tank Farms Field Crew - Initial Qualification

Solid Waste Project - Waste Operations

Opentions $\mathrm{Cl}$ assroom

Push Mode Sampling Operations - Initial Qualification

Rotary Mode Sampling Operations - Initial Qualification

Ground Crew - Initial QuaTification

Tank Farms Saltwel1 Systems Operations - Initial Qualification

Tank Farms Drywe1]/Low Van Operations - Initial Qualification

204-AR Operations - Initial Qualification

TWRS Operations Engineer Qualification

Solid Waste Project - Waste Operations Generator Services Sampling and Repacking Operations - Initial Qualification

Solid Waste Project - Waste Operations Generator-Services

Surveillance and Inspection - Initial Qualification

Solid Waste Project - Waste Operations Generator Services

Container Document System Dispatch - Initial Qualification

Tank Farms Mitigation Pump Operations - Initia1 Qualification

TMACS Operations - Initial Qualification

Tank Farms Person-In-Charge (PIC) Qualification - Initial \&

Refresher

Waste Handling Segregation and Packaging - Initial or Refresher

TWRS Waste Retrieval Qualification - Initial

Tank Farms Facility Orientation

Tank Farms Facility Re-0rientation

Field Sampling - Initial Qualification

Solid Waste Project - Waste Operations Truck Operations - Requalification

Cask/Sample Transport Truck Operations - Requalification 
350032

350036

350039

350042

350062

350073

350079

350082

350083

350092

350102

350147

350162

350163

350164

350182

350202

350682

351482

Tank Farms Routine - Requalification

Characterization Project Routine Operations - Requalification

CPO Routines Revised - Requalification (With In-Tank Video)

Tank Farms Aging Waste Operations - Requalification

Tank Farms Field Crew - Requalification

Rotary Mode Sampling Operations - RequaTification

Ground Crew - Requalification

Tank Farms Saltwell Systems Dperations - Requalification

Push Mode Sampling Operations - Requalification

Tank Farms Drywel7/Low Van Operations - Requalification

204-AR Operations - Requalification

TWRS Operations Engineer Requalification

Solid Waste Project - Waste Operations Sampling and Repacking Operations - Requalification

COURSES SUPERSEDED BY CURRENT COURSES

$000063 \quad$ Facility Orientation - East Tank Farm

000065 Facility Orientation - West Tank Farm

000077

020065

350110

350561

Facility Orientation - Tank Farms

Hazardous Waste Shipment Certification

Tank Farm Supervisor/Manager Certification

350700

Waste Handling Segregation and Packaging - Refresher

(Replaced by 350560 [Initial or Refresher])

350750

Tank Farm East Facility Orjentation

Tank Farm West Facility Orientation 
HNF-SD-WM-TR-026 Rev. 9

\section{Appendix A Training Course Descriptions}

\section{TABLE OF CONTENTS}

Appendix A-1 Dangerous Waste Operations Training Courses ....... A-1

Appendix A-2 Job-Specific Training Courses ............ A - 9 
Appendix A-1 Dangerous Waste Operations Training Courses

\begin{tabular}{|c|c|}
\hline Title & 000001 Hanford General Employee Training (HGET) \\
\hline Description & $\begin{array}{l}\text { Course covers U.S. Department of Energy orders and } \\
\text { applicable policies pertaining to employer and employee } \\
\text { rights and responsibilities, general radiation training, } \\
\text { hazardous communications and dangerous waste, fire } \\
\text { prevention, personal protective equipment, safety } \\
\text { requirements, emergency preparedness, accident reporting, } \\
\text { and avenues for addressing safety concerns. The RCRA } \\
\text { training program identifies this course as a program } \\
\text { element as annual refresher to the Hanford Facility RCRA } \\
\text { Permit condition concerning training. }\end{array}$ \\
\hline $\begin{array}{l}\text { Mandating } \\
\text { Document (s) }\end{array}$ & Hanford Faci]ity RCRA Permit, General Conditions II.C \\
\hline Target audience & $\begin{array}{l}\text { A11 Hanford Facility personnel working on the Hanford } \\
\text { Facility more than one year. }\end{array}$ \\
\hline Delivery & Computer-based training with interactive video \\
\hline Evaluation & Computer generated questions \\
\hline Length & Average $=2$ to 4 Hours \\
\hline Frequency & Annua71y by 000001 \\
\hline
\end{tabular}

\begin{tabular}{|c|c|}
\hline Title & 000090 Visitor/Vendor Orientation (Video or Brochure) \\
\hline Description & $\begin{array}{l}\text { Course is designed to acquaint and familiarize visitors } \\
\text { and subcontractors with safety, security, and emergency } \\
\text { preparedness requirements and their responsibilities to } \\
\text { notify Hanford Facility personnel when situations arise. } \\
\text { In addition, this orientation identifies the need to obey } \\
\text { signs and labels that may be encountered regarding } \\
\text { radiological areas, hazardous materials, and dangerous } \\
\text { waste. }\end{array}$ \\
\hline $\begin{array}{l}\text { Mandating } \\
\text { Document (s) }\end{array}$ & Hanford Facility RCRA Permit, General Conditions II.C \\
\hline Target audience & $\begin{array}{l}\text { Visitors on site }>7 \text { days, including regulatory agency } \\
\text { personnel. LMHC subcontractors working on the Hanford } \\
\text { Facility }<45 \text { days. }\end{array}$ \\
\hline Delivery & Video Tape or Brochure \\
\hline Evaluation & Not App i icable \\
\hline Length & 30 Minutes \\
\hline Frequency & Annually by 000090 \\
\hline
\end{tabular}


Appendix A-1 (Continued) Dangerous Waste Operations Training Courses

\begin{tabular}{|c|c|}
\hline Title & 02006G Waste Management Awareness \\
\hline Description & $\begin{array}{l}\text { Course introduces workers to federal laws governing } \\
\text { chemical safety in the work place. The course provides } \\
\text { the hazardous material/waste worker with the basic } \\
\text { fundamentals for safe use of hazardous material. Course } \\
\text { defines hazard communication and hazardous materials and } \\
\text { accumulation of waste in containers. The concepts } \\
\text { covered in this course instruct personnel on specific } \\
\text { waste generation procedures and requirements which } \\
\text { includes: (1) Pertinent waste management issues (e.g. } \\
\text { waste categories, initial accumulation container } \\
\text { management requirements, and waste segregation } \\
\text { practices), (2) proper responses to incidents pertaining } \\
\text { to the waste in the initial accumulation containers, } \\
\text { (3) Proper responses to dealing with waste of unknown } \\
\text { origins, and (4) proper responses to questions posed in } \\
\text { the field concerning the above elements. }\end{array}$ \\
\hline $\begin{array}{l}\text { Mandating } \\
\text { Document }(s)\end{array}$ & $\begin{array}{l}\text { DOE-RL letter to Ecology responding to Consent Order NO. } \\
\text { DE 94NM-063 } \\
\text { Hanford Facility RCRA Permit, Genera7 Conditions II.C.4 }\end{array}$ \\
\hline Target audience & $\begin{array}{l}\text { General worker, advanced general worker, general manager, } \\
\text { and general shipper }\end{array}$ \\
\hline Delivery & Classroom \\
\hline Evaluation & Written examination - $80 \%$ passing grade \\
\hline Length & 4 Hours \\
\hline Frequency & One Time \\
\hline
\end{tabular}


Appendix A-1 (Continued) Dangerous Waste Operations Training Courses

\begin{tabular}{||l|l||}
\hline Title & $\begin{array}{l}020159 \text { Hazardous Waste Shipper Qualification - Advanced } \\
\text { Course 2 }\end{array}$ \\
\hline Description & $\begin{array}{l}\text { Course introduces General Shippers to identify shippers ' } \\
\text { responsibilities and } 1 \text { iabilities with regard to } \\
\text { compl iance to manifesting requirements and D0T } \\
\text { regulations, including placarding, identifying proper } \\
\text { shipping names, and loading requirements. }\end{array}$ \\
\hline $\begin{array}{l}\text { Mandating } \\
\text { Document (s) }\end{array}$ & $\begin{array}{l}\text { WAC 173-303-330(1), -180, -190, and -370. } \\
\text { Hanford Facility RCRA Permit, General Condition II.Q. }\end{array}$ \\
\hline Target Audience & $\begin{array}{l}\text { General Shippers of dangerous or mixed waste on roadways } \\
\text { anywhere on the Hanford Facility. }\end{array}$ \\
\hline Delivery & Classroom \\
\hline Evaluation & Written examination - $80 \%$ passing grade \\
\hline Length & 24 Hours \\
\hline Frequency & Every 3 years by 020159 \\
\hline
\end{tabular}

\begin{tabular}{|c|c|}
\hline Title & 035010 Waste Designation \\
\hline Description & $\begin{array}{l}\text { Course teaches dangerous waste designation according to } \\
\text { Washington Administrative Code (WAC) 173-303. Class } \\
\text { content includes section-by-section lecture on the } \\
\text { regulations, with examples following each section. } \\
\text { Students complete examples using a Waste Designation flow } \\
\text { chart. Examples addressed include: Federal Listed Waste, } \\
\text { Discarded Chemical Products, Dangerous Waste Source, } \\
\text { Washington State Criteria: Toxicity, Persistence, } \\
\text { Carcinogenic, and Federal Characteristics: Ignitability, } \\
\text { Corrosivity, Reactivity, and Toxicity. }\end{array}$ \\
\hline $\begin{array}{l}\text { Mandating } \\
\text { Document (s) }\end{array}$ & WAC $173-303-070$, and -080 through -100 \\
\hline Target Audience & $\begin{array}{l}\text { General Shippers, General Manager (Generator Services } \\
\text { Operators On1y), Waste Designator }\end{array}$ \\
\hline Delivery & Classroom \\
\hline Evaluation & Written Exam - $80 \%$ passing grade \\
\hline Length & 16 Hours \\
\hline Frequency & One Time \\
\hline
\end{tabular}


Appendix A-1 (Continued) Dangerous Waste Operations Training Courses

\begin{tabular}{||l|l||}
\hline Title & 035012 Waste Designation Qualification \\
\hline Description & $\begin{array}{l}\text { Course provides qualification to become a waste } \\
\text { designator. }\end{array}$ \\
\hline $\begin{array}{l}\text { Mandating } \\
\text { Document(s) }\end{array}$ & WAC $173-303-070$, and -080 through -100 \\
\hline Target Audience & Waste Designators \\
\hline Delivery & Classroom \\
\hline Evaluation & Written Exam - 80\% passing grade \\
\hline Length & 4 Hours \\
\hline Frequency & Annually by 035012 \\
\hline
\end{tabular}

\begin{tabular}{|c|c|}
\hline Title & 035020 Facility Waste Sampling and Analys is \\
\hline Description & $\begin{array}{l}\text { Course presents waste sampling methodologies according to } \\
\text { EPA Protocols SW-846, Test Methods for Evaluating Solid } \\
\text { Waste Physical/Chemical Methods. This course also covers } \\
\text { documentation requirements in a sampling plan, waste } \\
\text { analysis plan, field and laboratory quality } \\
\text { control/assurance, data quality objectives process and use } \\
\text { of actual sampling equipment as specified by WAC 173-303- } \\
110 \text {. Topics on listed waste management pertaining to } \\
\text { sample management and available on-site sampling services } \\
\text { are covered. }\end{array}$ \\
\hline $\begin{array}{l}\text { Mandating } \\
\text { Document (s) }\end{array}$ & WAC-173-303-330(1), $-070,-110$, and -300 \\
\hline Target audience & General Shippers \\
\hline Delivery & $\begin{array}{l}\text { Classroom presentation, exercises, demonstration and } \\
\text { discussion }\end{array}$ \\
\hline Evaluation & Written Examination - $80 \%$ passing grade \\
\hline Length & 16 Hours \\
\hline Frequency & One Time \\
\hline
\end{tabular}


Appendix A-1 (Continued) Dangerous Waste Operations Training Courses

\begin{tabular}{||l|l||}
\hline \hline Title & 035100 Container Waste Management - Initial \\
\hline Description & $\begin{array}{l}\text { Course covers general training requirements pertaining to } \\
\text { waste management in container at 90-day accumulation } \\
\text { areas and TSD units. The course incorporates WAC 173- } \\
303-200(1),-630, \text { DOE Orders, and LMHC pol icy for } \\
\text { container management. Includes practical exercises for } \\
\text { hands-on experience with the packaging of dangerous or } \\
\text { mixed waste, and preparation of packages for final } \\
\text { destination. } \\
\text { This course does not cover waste management aspects } \\
\text { pertaining to other RCRA waste management units such as } \\
\text { tank systems, surface impoundments, containment } \\
\text { buildings, landfil1s, etc. }\end{array}$ \\
\hline $\begin{array}{l}\text { Mandating } 173-303-330(1),-630,-200(1) \text { and Waste Minimization } \\
\text { Document(s) }\end{array}$ & $\begin{array}{l}\text { Advanced General Workers/General Managers Services / } \\
\text { Shippers }\end{array}$ \\
\hline Target Audience & Classroom \\
\hline Delivery & Written Examination - 80\% passing grade \\
\hline Evaluation & Annual1y by 035110 \\
\hline Length & Frequency
\end{tabular}

\begin{tabular}{||l|l||}
\hline Title & 035110 Container Waste Management - Refresher \\
\hline Description & Refreshes Course 035100 \\
\hline $\begin{array}{l}\text { Mandating } \\
\text { Document (s) }\end{array}$ & WAC 173-303-330(1),-630,-200(1) and Waste Minimization \\
\hline Target Audience & Advanced Genera1 Workers/General Managers/Shippers \\
\hline Delivery & Classroom \\
\hline Evaluation & Written Examination - 80\% passing grade \\
\hline Length & 4 Hours \\
\hline Frequency & Annual1y by 035110 \\
\hline
\end{tabular}




\section{Appendix A-1 (Continued) Dangerous Waste Operations Training Courses}

\begin{tabular}{||l|l||}
\hline \hline Title & 035120 Waste Management Administrative - Initial \\
\hline Description & $\begin{array}{l}\text { Course is designed for personnel preparing to become } \\
\text { shippers of dangerous and/or mixed waste. This course } \\
\text { covers regulatory and company policies, forms, reports, } \\
\text { forecasts, and plans. Topics al so covered include: waste } \\
\text { characterization, waste storage disposal request, 1ow } \\
\text { level waste storage/disposal record, transuranic waste } \\
\text { storage/disposal record, and radioactive mixed waste } \\
\text { attachment sheet. In addition, students wil1 1earn how } \\
\text { these forms are used to complete shipping papers. }\end{array}$ \\
\hline $\begin{array}{l}\text { Mandating } \\
\text { Document(s) }\end{array}$ & $\begin{array}{l}\text { WAC 173-303-330(1), -630, -200, -210, -220, -380, and - } \\
390 .\end{array}$ \\
\hline Target Audience & $\begin{array}{l}\text { Generator Managers (Generator Services 0perators } \\
\text { Only)/Waste Designator }\end{array}$ \\
\hline Delivery & Classroom \\
\hline Evaluation & Written Examination - 80\% passing grade \\
\hline Length & Annually by 035130 \\
\hline Frequency &
\end{tabular}

\begin{tabular}{||l|l||}
\hline Title & 035130 Waste Management Administrative - Refresher \\
\hline Description & Refreshes course 035120 \\
\hline $\begin{array}{l}\text { Mandating } \\
\text { Document(s) }\end{array}$ & $\begin{array}{l}\text { WAC } 173-303-330(1),-630,-200,-210,-220,-380 \text {, and - } \\
390 .\end{array}$ \\
\hline Target Audience & $\begin{array}{l}\text { General Managers (Generator Services Operators } \\
\text { Only)/Waste Designator }\end{array}$ \\
\hline Delivery & Classroom \\
\hline Evaluation & Written Examination - 80\% passing grade \\
\hline Length & 4 Hours \\
\hline Frequency & Annually by 035130 \\
\hline \hline
\end{tabular}




\section{Appendix A-1 (Continued) Dangerous Waste Operations Training Courses}

\begin{tabular}{||l|l||}
\hline Title & $\begin{array}{l}\text { 03E060 Facility Emergency and Hazard Information } \\
\text { Checklist Training (Building Emergency Plan Review for } \\
\text { HNF-IP-0263-TANKFARMS) }\end{array}$ \\
\hline Description & $\begin{array}{l}\text { Course consists of a review of specific hazards } \\
\text { associated with the TSD unit and employee's job. The } \\
\text { training is completed by the supervisor, manager or a } \\
\text { designated individual using a checklist. The job- } \\
\text { specific information is reviewed concerning hazards in } \\
\text { the employee's work area and Emergency Response } \\
\text { requirements, including were applicable, waste feed } \\
\text { cut-off, communication and alarm systems, and response to } \\
\text { fires. The checklist act as a guide to ensure consistent } \\
\text { coverage of necessary topics. }\end{array}$ \\
\hline Mandating \\
Document(s)
\end{tabular}$\quad$\begin{tabular}{l} 
WAC 173-303-330(1) (d), -340, -350, and -630. \\
\hline Target audience
\end{tabular}

\begin{tabular}{||l|l||}
\hline Title & $\begin{array}{l}350560 \text { Waste Handling Segregation and Packaging - Initial } \\
\text { or Refresher }\end{array}$ \\
\hline Description & $\begin{array}{l}\text { This course covers the proper handling, segregating and } \\
\text { packaging of waste within Tank Farms, The following } \\
\text { material is presented: Appl icable Regulations, Waste } \\
\text { Minimization, Waste Segregation, Waste Packaging Rules } \\
\text { for handling Radioactive Mixed Waste, including the use } \\
\text { of Satellite Accumulation Areas, and Required Inspections } \\
\text { of Accumulation Areas and Containers. }\end{array}$ \\
\hline $\begin{array}{l}\text { Mandating } \\
\text { Document(s) }\end{array}$ & $\begin{array}{l}\text { WAC 173-303-330( } 1 \text { )(d), -200, -300, and waste } \\
\text { minimization. }\end{array}$ \\
\hline Target Audience & $\begin{array}{l}\text { General Workers/Advanced General Workers/General } \\
\text { Managers/General Shippers }\end{array}$ \\
\hline Delivery & Classroom \\
\hline Evaluation & Written Examination - 70\% passing grade \\
\hline Length & 4 Hours \\
\hline Frequency & Annually by 350560 \\
\hline \hline
\end{tabular}




\section{Appendix A-1 (Continued) Dangerous Waste Operations Training Courses}

\begin{tabular}{|c|c|}
\hline Title & 350710 Tank Farms Facility Orientation \\
\hline Description & $\begin{array}{l}\text { Course consists of classroom presentation. Topics are } \\
\text { presented according to U.S. Department of Energy, } \\
\text { Federal, and State requirements that include entry and } \\
\text { exit requirements; location of organizational charts and } \\
\text { administrative and operating procedures; the person in } \\
\text { charge of communications; potential hazards (radiological } \\
\text { and nonradiological); restricted areas; potential } \\
\text { emergencies, alarms, communications, responses and } \\
\text { staging areas; locations and use of personal protective } \\
\text { and emergency equipment; identification of TSD units; } \\
\text { overview of the process; and training requirements. }\end{array}$ \\
\hline $\begin{array}{l}\text { Mandating } \\
\text { Document (s) }\end{array}$ & WAC $-173-303-330(1),-340,-350$, and -360 \\
\hline Target audience & A11 Personnel entering TWRS TSD Units \\
\hline Delivery & C1 assroom \\
\hline Evaluation & Written examination - $70 \%$ passing grade \\
\hline Length & 3 Hours \\
\hline Frequency & Annual1y by 350760 (Computer-Based Training) \\
\hline
\end{tabular}

\begin{tabular}{||l|l||}
\hline \hline Title & 350760 Tank Farms Facility Re-Orientation \\
\hline Description & $\begin{array}{l}\text { Course consists of a review of entry and exit } \\
\text { requirements; location of organizational charts and } \\
\text { administrative and operating procedures; the person in } \\
\text { charge of communications; potential hazards (radiological } \\
\text { and nonradiological); restricted areas; potent ia } \\
\text { emergencies, alarms, communications, responses and } \\
\text { staging areas; locations and use of personal protective } \\
\text { and emergency equipment; identification of TSD units; } \\
\text { overview of the process; and training requirements. }\end{array}$ \\
\hline $\begin{array}{l}\text { Mandating } \\
\text { Document(s) }\end{array}$ & \begin{tabular}{l} 
WAC-173-303-330(1), -340, -350, and -360 \\
\hline Target audience
\end{tabular} \\
\hline All Personnel entering TWRS TSD Units \\
\hline Evaluation & Computer-based Training \\
\hline Length & Not applicable \\
\hline Frequency & Annually with 00000I \\
\hline
\end{tabular}




\section{Appendix A-2 Job-Specific Training Courses}

\begin{tabular}{||l|l||}
\hline Title & 02028B Building Emergency Director Training \\
\hline Description & $\begin{array}{l}\text { Course provides an overview of the responsibilities of } \\
\text { the building emergency director, identifies the building } \\
\text { emergency organizations, actions required during an } \\
\text { event, implementing the contingency plan, and discusses } \\
\text { dri1l and exercise requirements. }\end{array}$ \\
\hline $\begin{array}{l}\text { Mandating } \\
\text { Document(s) }\end{array}$ & WAC-173-303-330(1),-340, -350, and -360 \\
\hline Target audience & $\begin{array}{l}\text { Operations Shift Managers/Operations Engineers } \\
\text { (Designated Building Emergency Directors)/Operations } \\
\text { Managers }\end{array}$ \\
\hline Delivery & At the BED office \\
\hline Evaluation & Performance Evaluation \\
\hline Length & 3.5 Hours \\
\hline Frequency & Annually by 0375l0 \\
\hline
\end{tabular}

\begin{tabular}{||l|l||}
\hline \hline Title & $\begin{array}{l}037510 \text { Building Emergency Director/Building Warden } \\
\text { Requalification }\end{array}$ \\
\hline Description & Refresher for Building Emergency Director Training \\
\hline $\begin{array}{l}\text { Mandating } \\
\text { Document(s) }\end{array}$ & WAC-173-303-330(1), -340, -350, and -360 \\
\hline Target audience & $\begin{array}{l}\text { Operations Shift Managers/Operations Engineers } \\
\text { (Designated Building Emergency Directors)/Operations } \\
\text { Managers }\end{array}$ \\
\hline Delivery & Classroom \\
\hline Evaluation & Not Applicable \\
\hline Length & 1.5 Hours \\
\hline Frequency & Annual1y by 037510 \\
\hline
\end{tabular}




\section{Appendix A-2 (Continued) Job-Specific Training Courses}

\begin{tabular}{|c|c|}
\hline Title & $\begin{array}{l}350010 \text { Solid Waste Project - Waste Operations Generator } \\
\text { Services Truck Operations - Initial Qualification }\end{array}$ \\
\hline Description & $\begin{array}{l}\text { Operator qualification course that covers the } \\
\text { requirements to move dangerous waste from the field and } \\
\text { satellite accumulation areas to the }<90 \text { day storage pad, } \\
\text { communication and alarm systems and response to dangerous } \\
\text { waste contamination. The qual ification course includes } \\
\text { completion of Tank Farms Waste Truck Operation classroom } \\
\text { and on-the-job training checklist. }\end{array}$ \\
\hline $\begin{array}{l}\text { Mandating } \\
\text { Document (s) }\end{array}$ & $W A C-173-303-330,-400$ or -600 \\
\hline Target audience & Nuclear Chemical Operators \\
\hline Delivery & Classroom, On-The-Job Training \\
\hline Evaluation & $\begin{array}{l}\text { Written Examination - } 70 \% \text { passing grade, Performance } \\
\text { Demonstration }\end{array}$ \\
\hline Length & Approximately 20 Hours \\
\hline Frequency & Every 2 years by 350012 \\
\hline
\end{tabular}

\begin{tabular}{||l|l||}
\hline Title & $\begin{array}{l}350020 \text { Cask/Sample Transport Truck Operations - Initial } \\
\text { Qualification }\end{array}$ \\
\hline Description & $\begin{array}{l}\text { Operator qualification course that covers the } \\
\text { requirements to transport samples from the field to the } \\
\text { laboratories. The qualification course includes } \\
\text { completion of Cask/Sample Transport Truck Operations } \\
\text { Classroom and on-the-job training checklist. }\end{array}$ \\
\hline $\begin{array}{l}\text { Mandating } \\
\text { Document(s) }\end{array}$ & WAC-173-303-330, -400 or -600 \\
\hline Target audience & Nuclear Chemical Operators \\
\hline Delivery & Classroom, On-the-Job Training \\
\hline Evaluation & $\begin{array}{l}\text { Written Examination - 70\% passing grade, Performance } \\
\text { Demonstration }\end{array}$ \\
\hline Length & Approximately 40 Hours \\
\hline Frequency & Every 2 years by 350022 \\
\hline
\end{tabular}




\section{Appendix A-2 (Continued) Job-Specific Training Courses}

\begin{tabular}{|c|c|}
\hline Title & $\begin{array}{l}350030 \text { Tank Farms Routine Operations - Initial } \\
\text { Qualification }\end{array}$ \\
\hline Description & $\begin{array}{l}\text { Operator qualification course that defines the } \\
\text { function, components, principles of operation, and } \\
\text { purpose of Tank Farms Routine operations, Covers Alarm } \\
\text { response and normal operating procedures including: } \\
\text { procedures for using, inspecting and replacing TWRS } \\
\text { emergency and monitoring equipment, automatic and manual } \\
\text { dangerous waste feed cut-off systems, response to fire } \\
\text { and explosions, response to spills and shutdown of } \\
\text { operations. }\end{array}$ \\
\hline $\begin{array}{l}\text { Mandating } \\
\text { Document (s) }\end{array}$ & $W A C-173-303-330,-400$ or -600 \\
\hline Target audience & Nuclear Chemical Operators \\
\hline Delivery & Classroom, on-The-Job Training \\
\hline Evaluation & $\begin{array}{l}\text { Written Examination - } 70 \% \text { passing grade, Performance } \\
\text { Demonstration }\end{array}$ \\
\hline Length & Approximately $160 \mathrm{hrs}$ \\
\hline Frequency & Every 2 Years by 350032 \\
\hline
\end{tabular}

\begin{tabular}{||l|l|}
\hline \hline Title & 350031 Tank Farms Routines Classroom \\
\hline Description & $\begin{array}{l}\text { This classroom training teaches Operators how to perform } \\
\text { duties associated with routine surveillance, waste } \\
\text { transfers and ventilation in Tank Farms. Conduct of } \\
\text { Operations, equipment, alarm response, radiation control, } \\
\text { and safety requirements are also covered. }\end{array}$ \\
\hline $\begin{array}{l}\text { Mandating } \\
\text { Document(s) }\end{array}$ & WAC-173-303-330, -400 or -600 \\
\hline Target audience & Nuclear Chemical Operators \\
\hline Delivery & Classroom \\
\hline Evaluation & Written Examination - 70\% passing grade \\
\hline Length & Approximately 160 hrs \\
\hline Frequency & Initial Training \\
\hline
\end{tabular}




\section{Appendix A-2 (Continued) Job-Specific Training Courses}

\begin{tabular}{||l|l||}
\hline Title & $\begin{array}{l}350035 \text { Characterization Project Routine Operations - } \\
\text { Initial Qualification }\end{array}$ \\
\hline Description & $\begin{array}{l}\text { Operator qual ification course that defines the } \\
\text { function, components, principles of operation and } \\
\text { purpose of CP0 Routines Covers procedures for using, } \\
\text { inspecting and replacing tools and equipment and response } \\
\text { to spil1s. }\end{array}$ \\
\hline $\begin{array}{l}\text { Mandating } \\
\text { Document (s) }\end{array}$ & WAC-173-303-330, -400 or -600 \\
\hline Target audience & Nuclear Chemical Operators \\
\hline Delivery & Classroom, On-The-Job Training \\
\hline Evaluation & $\begin{array}{l}\text { Written Examination - 70\% passing grade, Performance } \\
\text { Demonstration }\end{array}$ \\
\hline Length & Approximately 40 Hours \\
\hline Frequency & Every 2 Years by 350036 \\
\hline
\end{tabular}

\begin{tabular}{||l|l||}
\hline \hline Title & $\begin{array}{l}350037 \text { CPO Routines Revised Qualification (With In-Tank } \\
\text { Video) }\end{array}$ \\
\hline Description & $\begin{array}{l}\text { Operator qualification course that defines the } \\
\text { function, components, principles of operation and } \\
\text { purpose of CPO Routines Covers procedures for using, } \\
\text { inspecting and replacing tools and equipment including } \\
\text { In-Tank Video equipment and response to spills. }\end{array}$ \\
\hline $\begin{array}{l}\text { Mandating } \\
\text { Document(s) }\end{array}$ & WAC-173-303-330, -400 or -600 \\
\hline Target audience & Nuclear Chemical Operators \\
\hline Delivery & Classroom, On-The-Job Training \\
\hline Evaluation & $\begin{array}{l}\text { Written Examination - 70\% passing grade, Performance } \\
\text { Demonstration }\end{array}$ \\
\hline Length & Approximately 1 Hour \\
\hline Frequency & Every 2 Years by 350039 \\
\hline
\end{tabular}




\section{Appendix A-2 (Continued) Job-Specific Training Courses}

\begin{tabular}{||l|l||}
\hline Title & $\begin{array}{l}350040 \text { Tank Farms Aging Waste Operations - Initial } \\
\text { Qualification }\end{array}$ \\
\hline Description & $\begin{array}{l}\text { Operator qual ification course that defines the } \\
\text { function, components, principles of operation, and } \\
\text { purpose of Aging Waste operations. Covers Alarm Response } \\
\text { Procedures and normal operating procedures including: } \\
\text { procedures for using, inspecting and replacing TWRS } \\
\text { emergency and monitoring equipment, automatic and manual } \\
\text { dangerous waste feed cut-off systems, response to fire } \\
\text { and explosions, response to spills and shutdown of } \\
\text { operations. }\end{array}$ \\
\hline $\begin{array}{l}\text { Mandating } \\
\text { Document(s) }\end{array}$ & \begin{tabular}{l} 
WAC-173-303-330, -400 or -600 \\
\hline Target audience
\end{tabular} \\
\hline Delivery & $\begin{array}{l}\text { Nuclear Chemical 0perators } \\
\text { Classroom, On-The-Job Training }\end{array}$ \\
\hline Evaluation & Approximately 40 hrs \\
\hline Length & Every 2 Vears by 350042 \\
\hline Frequency &
\end{tabular}

\begin{tabular}{||l|l||}
\hline Title & 350060 Tank Farms Field Crew - Initial Qualification \\
\hline Description & $\begin{array}{l}\text { Operator qualification course that defines the } \\
\text { function, components, principles of operation and } \\
\text { purpose of Field Crew, Covers procedures for using, } \\
\text { inspecting and replacing tools and equipment and response } \\
\text { to spil1s. }\end{array}$ \\
\hline $\begin{array}{l}\text { Mandating } \\
\text { Document (s) }\end{array}$ & WAC-173-303-330, -400 or -600 \\
\hline Target audience & Nuclear Chemical 0perators \\
\hline Delivery & Classroom, On-The-Job Training \\
\hline Evaluation & $\begin{array}{l}\text { Written Examination - 70\% passing grade, Performance } \\
\text { Demonstration }\end{array}$ \\
\hline Length & Approximately 60 Hours \\
\hline Frequency & Every 2 Years by 350062 \\
\hline
\end{tabular}


Appendix A-2 (Continued) Job-Specific Training Courses

\begin{tabular}{|c|c|}
\hline Title & $\begin{array}{l}350066 \text { Sol id Waste Project - Waste Operations } \\
\text { Senvices Operations Classroom }\end{array}$ \\
\hline Description & $\begin{array}{l}\text { Course covers the requirements to operate TWRS }<90 \text { day } \\
\text { storage pad, the movement of dangerous waste from } \\
\text { satellite accumulation areas to the }<90 \text { day storage pad, } \\
\text { defines the function, components, principles of } \\
\text { operation, and purpose of the waste truck and } \\
\text { requirements to support the shipment of Dangerous Waste. } \\
\text { Communication and alarm systems and response to dangerous } \\
\text { waste contamination. }\end{array}$ \\
\hline $\begin{array}{l}\text { Mandating } \\
\text { Document }(s)\end{array}$ & WAC $-173-303-330,-400$ or -600 \\
\hline Target audience & Generator Services, Advanced General Workers \\
\hline Delivery & Classroom \\
\hline Evaluation & $\begin{array}{l}\text { Written Examination - } 70 \% \text { passing grade for nuclear } \\
\text { operators, } 80 \% \text { for Generator Services Operations Team } \\
\text { Leaders }\end{array}$ \\
\hline Length & Approximately 8 Hours \\
\hline Frequency & One Time \\
\hline
\end{tabular}

\begin{tabular}{|l|l|}
\hline Title & $\begin{array}{l}\text { 350070 Push Mode Sampling Operations - Initial } \\
\text { Qual ification }\end{array}$ \\
\hline Description & $\begin{array}{l}\text { Operator qual ification course that defines the function, } \\
\text { components, principles of operation and purpose of Push } \\
\text { Mode Core Sampling Platform Operations. }\end{array}$ \\
\hline $\begin{array}{l}\text { Mandating } \\
\text { Document(s) }\end{array}$ & WAC-173-303-330, -400 or -600 \\
\hline Target audience & Nuclear Chemical Operators \\
\hline Delivery & Classroom, On-The-Job Training \\
\hline Evaluation & $\begin{array}{l}\text { Written Examination - 70\% passing grade, Performance } \\
\text { Demonstration }\end{array}$ \\
\hline Length & Approximately 40 Hours \\
\hline Frequency & Every 2 Years by 350083 \\
\hline
\end{tabular}




\section{Appendix A-2 (Continued) Job-Specific Training Courses}

\begin{tabular}{||l|l||}
\hline \hline Title & $\begin{array}{l}350075 \text { Rotary Mode Sampling Operations - Initial } \\
\text { Qualification }\end{array}$ \\
\hline Description & $\begin{array}{l}\text { Operator qual ification course that defines the } \\
\text { function, components, principles of operation and } \\
\text { purpose of Rotary Mode Sampling Platform Operations. }\end{array}$ \\
\hline $\begin{array}{l}\text { Mandating } \\
\text { Document(s) }\end{array}$ & WAC-173-303-330, -400 or -600 \\
\hline Target audience & Nuclear Chemical Operators \\
\hline Delivery & Classroom, On-The-Job Training \\
\hline Evaluation & $\begin{array}{l}\text { Written Examination - 70\% passing grade, Performance } \\
\text { Demonstration }\end{array}$ \\
\hline Length & Approximately 40 Hours \\
\hline Frequency & Every 2 Years by 350073 \\
\hline
\end{tabular}

\begin{tabular}{||l|l||}
\hline Title & 350077 Ground Crew - Initial Qualification \\
\hline Description & $\begin{array}{l}\text { Operator qual ification course that defines the } \\
\text { function, components, principles of operation and } \\
\text { purpose of Push and Rotary Mode Sampling Ground Crew } \\
\text { Operations. }\end{array}$ \\
\hline $\begin{array}{l}\text { Mandating } \\
\text { Document(s) }\end{array}$ & WAC-173-303-330, -400 or -600 \\
\hline Target audience & Nuclear Chemical Operators \\
\hline Delivery & Classroom, On-The-Job Training \\
\hline Evaluation & $\begin{array}{l}\text { Written Examination - 70\% passing grade, Performance } \\
\text { Demonstration }\end{array}$ \\
\hline Length & Approximately 40 Hours \\
\hline Frequency & Every 2 Years by 350079 \\
\hline
\end{tabular}




\section{Appendix A-2 (Continued) Job-Specific Training Courses}

\begin{tabular}{|c|c|}
\hline Title & $\begin{array}{l}350080 \text { Tank Farms Saltwell Systems Operations - Initia1 } \\
\text { Qualification }\end{array}$ \\
\hline Description & $\begin{array}{l}\text { Operator qualification course that defines the } \\
\text { function, components, principles of operation, and } \\
\text { purpose of Saltwell Systems operations. Covers Alarm } \\
\text { Response Procedures and normal operating procedures } \\
\text { including: procedures for automatic and manual dangerous } \\
\text { waste feed cut-off systems, response to spills and } \\
\text { shutdown of operations. }\end{array}$ \\
\hline $\begin{array}{l}\text { Mandating } \\
\text { Document }(s)\end{array}$ & WAC $-173-303-330,-400$ or -600 \\
\hline Target audience & Nuclear Chemical Operators \\
\hline Delivery & Classroom, On-The-Job Training \\
\hline Evaluation & $\begin{array}{l}\text { Written Examination - } 70 \% \text { passing grade, Performance } \\
\text { Demonstration }\end{array}$ \\
\hline Length & Approximate1y 24 Hours \\
\hline Frequency & Every 2 Years by 350082 \\
\hline
\end{tabular}

\begin{tabular}{||l|l||}
\hline Title & $\begin{array}{l}\text { 350090 Tank Farms Drywe 11/Low Van Operations - Initial } \\
\text { Qualification }\end{array}$ \\
\hline Description & $\begin{array}{l}\text { Operator qual ification course that defines the } \\
\text { function, components, principles of operation, and } \\
\text { purpose of Drywe11/Low Van operations and In-Tank } \\
\text { Photography and Video Taping. Covers alarm response and } \\
\text { normal operating procedures. }\end{array}$ \\
\hline $\begin{array}{l}\text { Mandating } \\
\text { Document(s) }\end{array}$ & WAC-173-303-330, -400 or -600 \\
\hline Target audience & Nuclear Chemical 0perators \\
\hline Delivery & Classroom, On-The-Job Training \\
\hline Evaluation & $\begin{array}{l}\text { Written Examination - 70\% passing grade, Performance } \\
\text { Demonstration }\end{array}$ \\
\hline Length & Approximately 24 Hours \\
\hline Frequency & Every 2 Years by 350092 \\
\hline
\end{tabular}




\begin{tabular}{||l|l||}
\hline Title & 350100 204-AR Operations - Initial Qualification \\
\hline Description & $\begin{array}{l}\text { Operator qual ification course that defines the } \\
\text { function, components, principles of operation, and } \\
\text { purpose of 204-AR Building operations Covers Alarm } \\
\text { Response Procedures and normal operating procedures } \\
\text { inc1uding: Automatic and manual dangerous waste feed } \\
\text { cut-off systems, response to fire and explosions, } \\
\text { response to spil1s and shutdown of operations. }\end{array}$ \\
\hline $\begin{array}{l}\text { Mandating } \\
\text { Document(s) }\end{array}$ & WAC-173-303-330, -400 or -600 \\
\hline Target audience & Nuclear Chemical Operators \\
\hline Delivery & Classroom, On-The-Job Training \\
\hline Evaluation & $\begin{array}{l}\text { Written Examination - 70\% passing grade, Performance } \\
\text { Demonstration }\end{array}$ \\
\hline Length & Approximately 40 Hours \\
\hline Frequency & Every 2 Years by 350102 \\
\hline \hline
\end{tabular}

\begin{tabular}{|c|c|}
\hline Title & 350145 TWRS Operations Engineer Qualification \\
\hline Description & $\begin{array}{l}\text { Course includes the following topics to prepare the } \\
\text { Manager in Tank Farms operations: } \\
\text { - Administrative information } \\
\text { - Technical information } \\
\text { - Hazardous material/dangerous waste requirements } \\
\text { - Safling dangerous waste } \\
\text { - Operational safety requirements } \\
\text { - Radiation work procedures } \\
\text { - Joburrence reporting } \\
\text { - Conduct of operations } \\
\text { - Erocesses and services }\end{array}$ \\
\hline $\begin{array}{l}\text { Mandating } \\
\text { Document (s) }\end{array}$ & WAC $-173-303-330,-400$ or -600 \\
\hline Target audience & Operations Shift Managers/Operations Engineers \\
\hline Del ivery & Classroom, On-The-Job Training \\
\hline Evaluation & Written Examination - $80 \%$ passing grade, Oral Board \\
\hline Length & 240 Hours \\
\hline Frequency & Every 2 years by 350147 \\
\hline
\end{tabular}


Appendix A-2 (Continued) Job-Specific Training Courses

\begin{tabular}{|c|c|}
\hline TitTe & $\begin{array}{l}350165 \text { Solid Waste Project - Waste Operations Genepatop } \\
\text { Services Sampling and Repacking Operations - Initial } \\
\text { Qualification }\end{array}$ \\
\hline Description & $\begin{array}{l}\text { Operator qualification course that covers the } \\
\text { requirements to sample and repack waste packages at the } \\
\text { <90 Day Storage Pad. Communication and alarm systems and } \\
\text { response to dangerous waste contamination. The } \\
\text { qualification course includes completion of Generator } \\
\text { Services Sampling and Repacking Operations Classroom and } \\
\text { on-the-job training checklist. }\end{array}$ \\
\hline $\begin{array}{l}\text { Mandating } \\
\text { Document }(s)\end{array}$ & $W A C-173-303-330,-400$ or -600 \\
\hline Target audience & Nuclear Chemical Operators \\
\hline Delivery & Classroom, On-The-Job Training \\
\hline Evaluation & $\begin{array}{l}\text { Written Examination - } 70 \% \text { passing grade, Performance } \\
\text { Demonstration }\end{array}$ \\
\hline Length & Approximately 40 Hours \\
\hline Frequency & Every 2 years by 350162 \\
\hline
\end{tabular}

\begin{tabular}{||l|l||}
\hline Title & $\begin{array}{l}350166 \text { Solid Waste Project - Waste Operations Generator } \\
\text { Services Surveillance and Inspection - Initial } \\
\text { Qualification }\end{array}$ \\
\hline Description & $\begin{array}{l}\text { Operator qualification course that covers the } \\
\text { requirements to operate TWRS } 90 \text { Day Storage Pad, the } \\
\text { movement of dangerous waste from satellite accumulation } \\
\text { areas to the <90 day storage pad and requirements to } \\
\text { support the shipment of Dangerous Waste. Communication } \\
\text { and alarm systems and response to dangerous waste } \\
\text { contamination. The certification course includes } \\
\text { completion of the Generator Services Surveillance and } \\
\text { Inspection 0peration Classroom and on-the-job training } \\
\text { checklist. }\end{array}$ \\
\hline Mandating \\
Document(s)
\end{tabular}




\section{Appendix A-2 (Continued) Job-Specific Training Courses}

\begin{tabular}{||l|l||}
\hline \hline Title & $\begin{array}{l}350167 \text { Solid Waste Project - Waste Operations Generat } \\
\text { Services Container Document System/Dispatch - Initial } \\
\text { Qualification }\end{array}$ \\
\hline Description & $\begin{array}{l}\text { Course covers the requirements to operate the } \\
\text { Environmenta1 Waste Operations Container Document System } \\
\text { to keep track of the Dangerous and Mixed Waste } \\
\text { accumulated by TWRS. }\end{array}$ \\
\hline $\begin{array}{l}\text { Mandating } \\
\text { Document(s) }\end{array}$ & WAC-173-303-330, -400 or -600 \\
\hline Target audience & Nuclear Chemical Operators \\
\hline Delivery & Classroom, On-The-Job Training \\
\hline Evaluation & By examination, Performance Demonstration \\
\hline Length & NA \\
\hline Frequency & Every 2 years 350164 \\
\hline
\end{tabular}

\begin{tabular}{||l|l||}
\hline Title & $\begin{array}{l}\text { 350180 Tank Farms Mitigation Pump Operations - Initial } \\
\text { Qualification }\end{array}$ \\
\hline Description & $\begin{array}{l}\text { Operator qual ification course that defines the } \\
\text { function, components, principles of operation, and } \\
\text { purpose of Tank Farms Mitigation Pump operations. Covers } \\
\text { Alarm response and norma } 1 \text { operating procedures. }\end{array}$ \\
\hline $\begin{array}{l}\text { Mandating } \\
\text { Document (s) }\end{array}$ & WAC-173-303-330, -400 or -600 \\
\hline Target audience & Nuclear Chemical Operators \\
\hline Delivery & Classroom, On-The-Job Training, Performance Demonstration \\
\hline Evaluation & $\begin{array}{l}\text { Written Examination - 70\% passing grade, Performance } \\
\text { Demonstration }\end{array}$ \\
\hline Length & Approximately 40 Hours \\
\hline Frequency & Every 2 Years by 350182 \\
\hline
\end{tabular}




\section{Appendix A-2 (Continued) Job-Specific Training Courses}

\begin{tabular}{|c|c|}
\hline Title & 350201 EASS/TMACS Operations - Initial Qual ification \\
\hline Description & $\begin{array}{l}\text { Operator qualification course that defines the } \\
\text { function, components, principles of operation, and } \\
\text { purpose of the Eomputer Aut } \\
\text { Eentrat futity the TMACS. Covers Alarm Response } \\
\text { Procedures and normal operating procedures. }\end{array}$ \\
\hline $\begin{array}{l}\text { Mandating } \\
\text { Document (s) }\end{array}$ & WAC $-173-303-330,-400$ or -600 \\
\hline Target audience & Nuclear Chemical Operators \\
\hline Delivery & Classroom, On-The-Job Training \\
\hline Evaluation & $\begin{array}{l}\text { Written Examination - } 70 \% \text { passing grade, Performance } \\
\text { Demonstration }\end{array}$ \\
\hline Length & Approximately 24 Hours \\
\hline Frequency & Every 2 Years by 350202 \\
\hline
\end{tabular}

\begin{tabular}{||l|l||}
\hline Title & $\begin{array}{l}\text { 350510 Tank Farms Person-In-Charge (PIC) Qualification - } \\
\text { Initial \& Refresher }\end{array}$ \\
\hline Description & $\begin{array}{l}\text { PIC Qualification Training consists of three phases: } \\
\text { Procedural Reviews (required reading), On-The-Job } \\
\text { Training, and Performance Evaluations. These phases } \\
\text { provide the PIC candidate with facility specific } \\
\text { experience, an understanding of administrative procedures } \\
\text { associated with their area(s) of responsibilities, and a } \\
\text { comprehensive evaluation of their performance. The } \\
\text { course is designed to prepare/qualify individuals } \\
\text { responsible for the quantity and quality of work } \\
\text { performed and who coordinate the actions of operators, } \\
\text { technicians and maintenance personnel. }\end{array}$ \\
\hline Mandating & $\begin{array}{l}\text { HNF-IP-0842, D0E Order 5480.20A } \\
\text { Document(s) }\end{array}$ \\
\hline Target audience & Person-In-Charge \\
\hline Delivery & Classroom, On-The-Job Training, Required Reading \\
\hline Evaluation & $\begin{array}{l}\text { Written Examination - 80\% passing grade, Performance } \\
\text { Demonstration }\end{array}$ \\
\hline Length & Approximately 40 Hours \\
\hline Frequency & Every 2 Years by 350510 \\
\hline
\end{tabular}


Appendix A-2 (Continued) Job-Specific Training Courses

\begin{tabular}{|c|c|}
\hline Title & 350680 TWRS Waste Retrieval Qualification - Initial \\
\hline Description & $\begin{array}{l}\text { Train 0perators on all aspects of sluicing operations, } \\
\text { including operation of peripheral equipment. }\end{array}$ \\
\hline $\begin{array}{l}\text { Mandating } \\
\text { Document }(s)\end{array}$ & WAC $173-303-330,-400$ or -600 \\
\hline Target audience & Nuclear Chemical Operators \\
\hline Delivery & Classroom, On-The-Job Training \\
\hline Evaluation & $\begin{array}{l}\text { Written Examination - } 70 \% \text { passing grade, Performance } \\
\text { Demonstration }\end{array}$ \\
\hline Length & Approximately 40 Hours \\
\hline Frequency & Every 2 Years by 350682 \\
\hline Title & 351479 Field Sampling - Initial Qualification \\
\hline Description & $\begin{array}{l}\text { Operator qualification course that defines the } \\
\text { function, components, principles of operation and } \\
\text { purpose of Vapor, Auger, and Grab Sampling. }\end{array}$ \\
\hline $\begin{array}{l}\text { Mandating } \\
\text { Document (s) }\end{array}$ & WAC $-173-303-330,-400$ or -600 \\
\hline Target audience & Nuclear Chemical Operators \\
\hline Delivery & Classroom, On-The-Job Training \\
\hline Evaluation & $\begin{array}{l}\text { Written Examination - } 70 \% \text { passing grade, Performance } \\
\text { Demonstration }\end{array}$ \\
\hline Length & Approximately 40 Hours \\
\hline Frequency & Every 2 Years by 351482 \\
\hline
\end{tabular}


Appendix A-2 (Continued) Job-Specific Training Courses

\begin{tabular}{|l|l||}
\hline Title & $\begin{array}{l}350012 \text { Solid Waste Project - Waste Operations Generator } \\
\text { Sefvices Truck Operations - Requalification }\end{array}$ \\
\hline Description & $\begin{array}{l}\text { Operator requalification that defines the function and } \\
\text { components, principles of operation and purpose of the } \\
\text { Generator Services Truck Operator. }\end{array}$ \\
\hline $\begin{array}{l}\text { Mandating } \\
\text { Document(s) }\end{array}$ & WAC-173-303-330, -400 or -600 \\
\hline Target audience & $\begin{array}{l}\text { Nuclear Chemical Operators Qualified Generator Services } \\
\text { Truck Operation }\end{array}$ \\
\hline Delivery & On-The-Job Training \\
\hline Evaluation & $\begin{array}{l}\text { Written Examination - 70\% passing grade, Performance } \\
\text { Demonstration or Evaluated Watch }\end{array}$ \\
\hline Length & N/A \\
\hline Frequency & Every 2 Years by 350012 \\
\hline
\end{tabular}

\begin{tabular}{|l|l||}
\hline Title & $\begin{array}{l}350022 \text { Cask/Sample Transport Truck Operations - } \\
\text { Requalification }\end{array}$ \\
\hline Description & $\begin{array}{l}\text { Operator requal ification that defines the function and } \\
\text { components, principles of operation and purpose of the } \\
\text { Cask/Sample Transport Truck Operator. }\end{array}$ \\
\hline $\begin{array}{l}\text { Mandating } \\
\text { Document(s) }\end{array}$ & WAC-173-303-330, -400 or -600 \\
\hline Target audience & $\begin{array}{l}\text { Nuclear Chemical Operators Qualified Cask/Sample } \\
\text { Transport Truck Operations Qualification }\end{array}$ \\
\hline Delivery & \begin{tabular}{l} 
Classroom, On-The-Job Training \\
\hline Evaluation
\end{tabular} \\
\hline $\begin{array}{l}\text { Written Examination - 70\% passing grade, Performance } \\
\text { Demonstration, or Evaluated Watch }\end{array}$ \\
\hline Length & Approximately 40 Hours \\
\hline Frequency & Every 2 Years by 350022 \\
\hline
\end{tabular}


Appendix A-2 (Continued) Job-Specific Training Courses

\begin{tabular}{||l|l||}
\hline Title & 350032 Tank Farms Routine - Requal ification \\
\hline Description & $\begin{array}{l}\text { Operator requalification that defines the function and } \\
\text { components, principles of operation and purpose of the } \\
\text { Tank Farms Routine Operator. }\end{array}$ \\
\hline $\begin{array}{l}\text { Mandating } \\
\text { Document(s) }\end{array}$ & WAC-173-303-330,-400 or -600 \\
\hline Target audience & $\begin{array}{l}\text { Nuclear ChemicaT Operators Qual ified Tank Farm Routine } \\
\text { Operations }\end{array}$ \\
\hline Delivery & Classroom, On-The-Job Training \\
\hline Evaluation & $\begin{array}{l}\text { Written Examination - 70\% passing grade, Performance } \\
\text { Demonstration, Evaluated Watch }\end{array}$ \\
\hline Length & Approximately 40 Hours \\
\hline Frequency & Every 2 Years by 350032 \\
\hline
\end{tabular}

\begin{tabular}{||l|l||}
\hline Title & $\begin{array}{l}350036 \text { Characterization Project Routine Operations - } \\
\text { Requalification }\end{array}$ \\
\hline Description & $\begin{array}{l}\text { Operator requalification course that defines the } \\
\text { function, components, principles of operation and } \\
\text { purpose of cP0 Routines. Covers procedures for using, } \\
\text { inspecting and replacing tools and equipment including } \\
\text { In-Tank Video and response to spil1s. }\end{array}$ \\
\hline $\begin{array}{l}\text { Mandating } \\
\text { Document(s) }\end{array}$ & WAC-173-303-330, -400 or -600 \\
\hline Target audience & Nuclear Chemical Operators \\
\hline Delivery & Classroom, On-The-Job Training \\
\hline Evaluation & Examination, Performance Demonstration \\
\hline Length & Approximately 40 Hours \\
\hline Frequency & Every 2 Years by 350036 \\
\hline \hline
\end{tabular}




\section{Appendix A-2 (Continued) Job-Specific Training Courses}

\begin{tabular}{||l|l||}
\hline Title & $\begin{array}{l}350039 \text { CPO Routines Revised - requalification (With In- } \\
\text { Tank Video) }\end{array}$ \\
\hline Description & $\begin{array}{l}\text { Operator requal ification course that defines the } \\
\text { function, components, principles of operation and } \\
\text { purpose of CPO Routines. Covers procedures for using, } \\
\text { inspecting and replacing tools and equipment including } \\
\text { In-Tank Video equipment and response to spi } 11 \text { s. }\end{array}$ \\
\hline $\begin{array}{l}\text { Mandating } \\
\text { Document (s) }\end{array}$ & WAC-173-303-330, -400 or -600 \\
\hline Target audience & Nuclear Chemical Operators \\
\hline Delivery & Classroom, 0n-The-Job Training \\
\hline Evaluation & $\begin{array}{l}\text { Written Examination - 70\% passing grade, Performance } \\
\text { Demonstration }\end{array}$ \\
\hline Length & NA \\
\hline Frequency & Every 2 Years by 350039 \\
\hline
\end{tabular}

\begin{tabular}{|c|c|}
\hline Title & $\begin{array}{l}350042 \text { Tank Farms Aging Waste Operations - } \\
\text { Requal ification }\end{array}$ \\
\hline Description & $\begin{array}{l}\text { Operator requalification that defines the function and } \\
\text { components, principles of operation and purpose of the } \\
\text { Tank Farm Aging Waste Operator. }\end{array}$ \\
\hline $\begin{array}{l}\text { Mandating } \\
\text { Document (s) }\end{array}$ & WAC-173-303-330, -400 or -600 \\
\hline Target audience & $\begin{array}{l}\text { Nuclear Chemical Operators Qual ified Tank Farms Aging } \\
\text { Waste Operations }\end{array}$ \\
\hline Delivery & Classroom, On-The-Job Training \\
\hline Evaluation & $\begin{array}{l}\text { Written Examination - } 70 \% \text { passing grade, Performance } \\
\text { Demonstration or Evaluated Watch }\end{array}$ \\
\hline Length & Approximately 40 Hours \\
\hline Frequency & Every 2 Years by 350042 \\
\hline
\end{tabular}




\section{Appendix A-2 (Continued) Job-Specific Training Courses}

\begin{tabular}{||l|l||}
\hline \hline Title & 350062 Tank Farms Field Crew - Requalification \\
\hline Description & $\begin{array}{l}\text { Operator requalification that defines the function and } \\
\text { components, principles of operation and purpose of the } \\
\text { Field Crew Operator. }\end{array}$ \\
\hline $\begin{array}{l}\text { Mandating } \\
\text { Document(s) }\end{array}$ & WAC-173-303-330, -400 or -600 \\
\hline Target audience & Nuclear Chemical Operators Qualified Field Crew \\
\hline Delivery & Classroom, 0n-The-Job Training \\
\hline Evaluation & $\begin{array}{l}\text { Written Examination - 70\% passing grade, Performance } \\
\text { Demonstration or Evaluated Watch }\end{array}$ \\
\hline Length & Approximately 20 Hours \\
\hline Frequency & Every 2 Years by 350062 \\
\hline
\end{tabular}

\begin{tabular}{||l|l||}
\hline Title & $\begin{array}{l}350073 \text { Rotary Mode Sampling Operations - } \\
\text { Requalification }\end{array}$ \\
\hline Description & $\begin{array}{l}\text { Operator requal ification that defines the function and } \\
\text { components, principles of operation and purpose of the } \\
\text { Rotary Sampling Operations. }\end{array}$ \\
\hline $\begin{array}{l}\text { Mandating } \\
\text { Document(s) }\end{array}$ & WAC-173-303-330, -400 or -600 \\
\hline Target audience & $\begin{array}{l}\text { Nuclear Chemical Operators Qualified Rotary Mode Sampling } \\
\text { Operator }\end{array}$ \\
\hline Delivery & Classroom, On-The-Job Training \\
\hline Evaluation & $\begin{array}{l}\text { Written Examination - 70\% passing grade, Performance } \\
\text { Demonstration or Evaluated Watch }\end{array}$ \\
\hline Length & Approximately 40 Hours \\
\hline Frequency & Every 2 Years by 350073 \\
\hline
\end{tabular}




\section{Appendix A-2 (Continued) Job-Specific Training Courses}

\begin{tabular}{||l|l||}
\hline Title & 350079 Ground Crew - Requalification \\
\hline Description & $\begin{array}{l}\text { Operator requalification that defines the function and } \\
\text { components, principles of operation and purpose of the } \\
\text { Ground Crew Operator. }\end{array}$ \\
\hline $\begin{array}{l}\text { Mandating } \\
\text { Document(s) }\end{array}$ & WAC-173-303-330,-400 or -600 \\
\hline Target audience & $\begin{array}{l}\text { Nuclear Chemical Operators Qual ified Ground Crew } \\
\text { Qual ification }\end{array}$ \\
\hline Delivery & Classroom, On-The-Job Training \\
\hline Evaluation & $\begin{array}{l}\text { Written Examination - 70\% passing grade, Performance } \\
\text { Demonstration or Evaluated Watch }\end{array}$ \\
\hline Length & Approximately 40 Hours \\
\hline Frequency & Every 2 Years by 350079 \\
\hline
\end{tabular}

\begin{tabular}{||l|l||}
\hline Title & $\begin{array}{l}350082 \text { Tank Farms Saltwel1 Systems Operations - } \\
\text { Requalification }\end{array}$ \\
\hline Description & $\begin{array}{l}\text { Operator requalification that defines the function and } \\
\text { components, principles of operation and purpose of the } \\
\text { SaltWell System Operator. }\end{array}$ \\
\hline $\begin{array}{l}\text { Mandating } \\
\text { Document(s) }\end{array}$ & WAC-173-303-330, -400 or -600 \\
\hline Target audience & $\begin{array}{l}\text { Nuclear Chemical Operators Qualified SaltWell System } \\
\text { Operations }\end{array}$ \\
\hline Delivery & Classroom, On-The-Job Training \\
\hline Evaluation & $\begin{array}{l}\text { Written Examination - 70\% passing grade, Performance } \\
\text { Demonstration or Evaluated Watch }\end{array}$ \\
\hline Length & Approximately 24 Hours \\
\hline Frequency & Every 2 Years by 350082 \\
\hline
\end{tabular}


Appendix A-2 (Continued) Job-Specific Training Courses

\begin{tabular}{|c|c|}
\hline Title & 350083 Push Mode Sampling Operations - Requalification \\
\hline Description & $\begin{array}{l}\text { Operator requalification that defines the function and } \\
\text { components, principles of operation and purpose of the } \\
\text { Push Mode Core Sampling Operator. }\end{array}$ \\
\hline $\begin{array}{l}\text { Mandating } \\
\text { Document (s) }\end{array}$ & $W A C-173-303-330,-400$ or -600 \\
\hline Target audience & $\begin{array}{l}\text { Nuclear Chemical Operators Qualified Push Mode Core } \\
\text { Sampling Operator Qualification }\end{array}$ \\
\hline Delivery & Classroom, On-The-Job Training \\
\hline Evaluation & $\begin{array}{l}\text { Written Examination - } 70 \% \text { passing grade, Performance } \\
\text { Demonstration or Evaluated Watch }\end{array}$ \\
\hline Length & Approximately 40 Hours \\
\hline Frequency & Every 2 Years by 350083 \\
\hline
\end{tabular}

\begin{tabular}{||l|l||}
\hline \hline Title & $\begin{array}{l}\text { 350092 Tank Farms Drywe11/LOW Van Operations - } \\
\text { Requalification }\end{array}$ \\
\hline Description & $\begin{array}{l}\text { Operator requal ification that defines the function, } \\
\text { components, and principles of operation and purpose of } \\
\text { the Drywe11/Low Van Operator. }\end{array}$ \\
\hline $\begin{array}{l}\text { Mandating } \\
\text { Document(s) }\end{array}$ & WAC-173-303-330, -400 or -600 \\
\hline Target audience & $\begin{array}{l}\text { Nuclear Chemical Operators Qualified Drywel1/LOW Van } \\
\text { Operations }\end{array}$ \\
\hline Delivery & Classroom, On-The-Job Training \\
\hline Evaluation & $\begin{array}{l}\text { Written Examination - 70\% passing grade, Performance } \\
\text { Demonstration or Evaluated Watch }\end{array}$ \\
\hline Length & Approximately 20 Hours \\
\hline Frequency & Every 2 Years by 350092 \\
\hline
\end{tabular}


Appendix A-2 (Continued) Job-Specific Training Courses

\begin{tabular}{||l|l||}
\hline Title & 350102 204-AR Operations - Requal ification \\
\hline Description & $\begin{array}{l}\text { Operator Requal ification defines the function and } \\
\text { components, principles of operation and purpose of the } \\
\text { 204-AR Operator. }\end{array}$ \\
\hline $\begin{array}{l}\text { Mandating } \\
\text { Document(s) }\end{array}$ & WAC-173-303-330,-400 or -600 \\
\hline Target audience & Nuclear Chemical Operators Qual ified 204-AR Operations \\
\hline Delivery & Classroom, On-The-Job Training \\
\hline Evaluation & $\begin{array}{l}\text { Written Examination - 70\% passing grade, Performance } \\
\text { Demonstration or Evaluated Watch }\end{array}$ \\
\hline Length & Approximately 20 Hours \\
\hline Frequency & Every 2 Years by 350102 \\
\hline
\end{tabular}

\begin{tabular}{||l|l||}
\hline Title & 350147 TWRS Operations Engineer Requalification \\
\hline Description & $\begin{array}{l}\text { Operations Engineer requal ification that defines the } \\
\text { function and components, principles of operation and } \\
\text { purpose of the Operations Engineer. }\end{array}$ \\
\hline $\begin{array}{l}\text { Mandating } \\
\text { Document(s) }\end{array}$ & WAC-173-303-330,-400 or -600 \\
\hline Target Audience & Operations Shift Managers/Operations Engineers \\
\hline Delivery & Examination \\
\hline Evaluation & By examination or Evaluated Watch \\
\hline Length & N/A \\
\hline Frequency & Every 2 years by 350147 \\
\hline
\end{tabular}




\section{Appendix A-2 (Continued) Job-Specific Training Courses}

\begin{tabular}{||l|l||}
\hline Title & $\begin{array}{l}350162 \text { Solid Waste Project - Waste Operations Generator } \\
\text { Service Sampling and Repackaging Operations - } \\
\text { Requal ification }\end{array}$ \\
\hline Description & $\begin{array}{l}\text { Operator requal ification that defines the function and } \\
\text { components, principles of operation and purpose of the } \\
\text { Environmenta1 Waste Operations Sampling/Repacking } \\
\text { Operator. }\end{array}$ \\
\hline $\begin{array}{l}\text { Mandating } \\
\text { Document(s) }\end{array}$ & WAC-173-303-330, -400 or -600 \\
\hline Target audience & $\begin{array}{l}\text { Nuclear Chemical Operators Qual ified Environmental Waste } \\
\text { Operations Sampling/Repacking Operations }\end{array}$ \\
\hline Delivery & On-The-Job Training \\
\hline Evaluation & $\begin{array}{l}\text { Written Examination - 70\% passing grade, Performance } \\
\text { Demonstration or Evaluated Watch }\end{array}$ \\
\hline Length & N/A \\
\hline Frequency & Every 2 Years by 350162 \\
\hline
\end{tabular}

\begin{tabular}{|c|c|}
\hline Title & $\begin{array}{l}350163 \text { Solid Waste Project - Waste Operations Genator } \\
\text { Servies Surveillance and Inspection - Requal ification }\end{array}$ \\
\hline Description & $\begin{array}{l}\text { Operator requalification that defines the function and } \\
\text { components, principles of operation and purpose of the } \\
\text { Environmental Waste Operations Surveillance/Inspection } \\
\text { Operator. }\end{array}$ \\
\hline $\begin{array}{l}\text { Mandating } \\
\text { Document }(s)\end{array}$ & WAC $-173-303-330,-400$ or -600 \\
\hline Target audience & $\begin{array}{l}\text { Nuclear Chemical Operators Qual ified Generator Services } \\
\text { Surveillance/Inspection Operation }\end{array}$ \\
\hline Delivery & On-The-Job Training \\
\hline Evaluation & Performance Demonstration or Evaluated Watch \\
\hline Length & Approximately 40 Hours \\
\hline Frequency & Every 2 Years by 350163 \\
\hline
\end{tabular}




\section{Appendix A-2 (Continued) Job-Specific Training Courses}

\begin{tabular}{||l|l||}
\hline \hline Title & $\begin{array}{l}350164 \text { Solid Waste Project - Waste Operations } \\
\text { fervice Container Document System Operations - } \\
\text { Requalification }\end{array}$ \\
\hline Description & $\begin{array}{l}\text { Operator requal ification that defines the requirements to } \\
\text { operate the Generator Services Operations Container } \\
\text { Document System to keep track of the Dangerous and Mixed } \\
\text { Waste accumulated by TWRS. }\end{array}$ \\
\hline $\begin{array}{l}\text { Mandating } \\
\text { Document(s) }\end{array}$ & WAC-173-303-330, -400 or -600 \\
\hline Target audience & Nuclear Chemical Operators \\
\hline Delivery & Classroom, On-The-Job Training \\
\hline Evaluation & By examination \\
\hline Length & Approximately 40 Hours \\
\hline Frequency & Every 2 years 350164 \\
\hline
\end{tabular}

\begin{tabular}{|c|c|}
\hline Title & $\begin{array}{l}350182 \text { Tank Farms Mitigation Pump Operations - } \\
\text { Requal ification }\end{array}$ \\
\hline Description & $\begin{array}{l}\text { Operator requalification course that defines the } \\
\text { function, components, principles of operation, and } \\
\text { purpose of TWRS Mitigation Pump operations. Covers Alarm } \\
\text { response and normal operating procedures }\end{array}$ \\
\hline $\begin{array}{l}\text { Mandating } \\
\text { Document }(s)\end{array}$ & $W A C-173-303-330,-400$ or -600 \\
\hline Target audience & $\begin{array}{l}\text { Nuclear Chemical Operators Qual ified Tank Farms } \\
\text { Mitigation Pump Operations }\end{array}$ \\
\hline Delivery & Classroom, on-The-Job Training \\
\hline Evaluation & $\begin{array}{l}\text { Written Examination - } 70 \% \text { passing grade, Performance } \\
\text { Demonstration }\end{array}$ \\
\hline Length & Approximately 40 Hours \\
\hline Frequency & Every 2 Years by 350182 \\
\hline
\end{tabular}




\begin{tabular}{||l|l||}
\hline Title & 350202 EASSTTMACS 0perations - Requal ification \\
\hline Description & $\begin{array}{l}\text { Operator requal ification that defines the function and } \\
\text { components, principles of operation and purpose of the } \\
\text { EASS TMACS Operator. }\end{array}$ \\
\hline $\begin{array}{l}\text { Mandating } \\
\text { Document (s) }\end{array}$ & WAC-173-303-330, -400 or -600 \\
\hline Target audience & $\begin{array}{l}\text { Nuclear Chemical Operators Qual ified EASS/TMACS } \\
\text { Operations }\end{array}$ \\
\hline Delivery & $\begin{array}{l}\text { Classroom, On-The-Job Training } \\
\text { Demonstration Examination - 70\% passing grade, Performance }\end{array}$ \\
\hline Evaluation & Approximately 8 Hours \\
\hline Length & Every 2 Years by 350202 \\
\hline Frequency
\end{tabular}

\begin{tabular}{||l|l||}
\hline Title & $\begin{array}{l}350682 \text { TWRS Waste Retrieval Qualification - } \\
\text { Requalification }\end{array}$ \\
\hline Description & $\begin{array}{l}\text { Train Operators on a17 aspects of Sluicing operations, } \\
\text { including operat ion of peripheral equipment. }\end{array}$ \\
\hline \begin{tabular}{l|l} 
Mandating \\
Document (s)
\end{tabular} & WAC $173-303-330,-400$ or -600 \\
\hline Target audience & Nuclear Chemical Operators \\
\hline Delivery & Classroom, 0n-The-Job Training \\
\hline Evaluation & $\begin{array}{l}\text { Written Examination - } 70 \% \text { passing grade, Performance } \\
\text { Demonstration }\end{array}$ \\
\hline Length & Approximately 40 Hours \\
\hline Frequency & Every 2 Years by 350682 \\
\hline
\end{tabular}




\begin{tabular}{|c|c|}
\hline Title & 351482 Field Sampling - Requalification \\
\hline Description & $\begin{array}{l}\text { Operator requalification that defines the function and } \\
\text { components, principles of operation and purpose of the } \\
\text { Field Sampling Operator. }\end{array}$ \\
\hline $\begin{array}{l}\text { Mandating } \\
\text { Document }(s)\end{array}$ & $W A C-173-303-330,-400$ or -600 \\
\hline Target audience & $\begin{array}{l}\text { Nuclear Chemical Operators Qualified Field Sampling } \\
\text { Operation }\end{array}$ \\
\hline Delivery & Classroom, On-The-Job Training \\
\hline Evaluation & $\begin{array}{l}\text { Written Examination - } 70 \% \text { passing grade, Performance } \\
\text { Demonstration or Evaluated Watch }\end{array}$ \\
\hline Length & Approximately 40 Hours \\
\hline Frequency & Every 2 Years by 351482 \\
\hline
\end{tabular}




\section{Appendix B Dangerous Waste Training Requirements Listed By Employee Job Position and Name (Examples)}

Appendix $B$ is maintained as required by HNF-IP-0974. These examples are provided to help explain the program. Copies of HNF-IP-0974 Can be found in the Shift Office at 272-AW and 272-WA.

Appendix B-1. TWRS Dangerous Waste Training Requirements For Advanced General Workers (Nuclear Chemical Operators) (EXAMPLE) . . . . . . B - 1

Appendix B-2. TWRS Dangerous Waste Training Requirements For General Managers (EXAMPLE) ................. B 4

Appendix B-3. TWRS Dangerous Waste Training Requirements For Genera 1 Shippers and Waste Designators (EXAMPLE) $B-7$ 
0
0
0
0
1
0
1
1
1
1
1
4
3
3

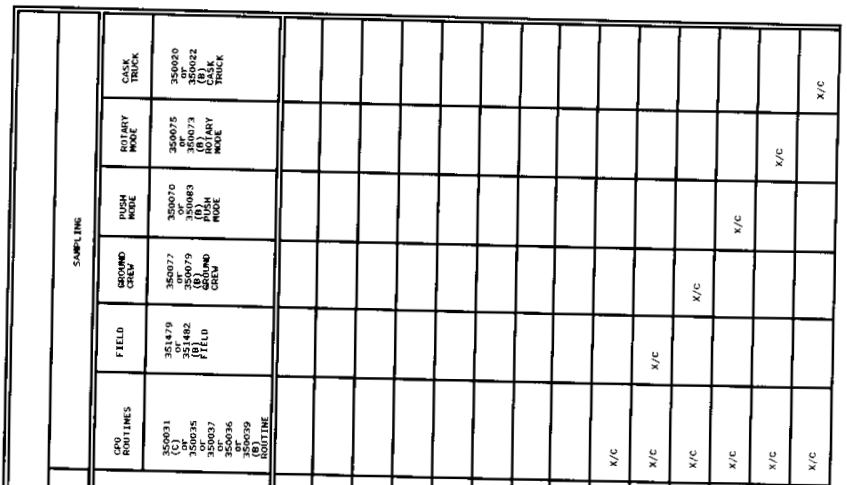

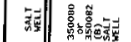

$\frac{1}{3}$

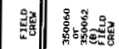

눈

\begin{tabular}{lll|l}
\hline & \\
\hline
\end{tabular}

is

+藏

恶

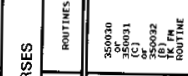

$=\frac{2}{5}$

蛋要

용

몽응

E

里

s

空

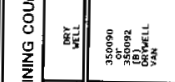

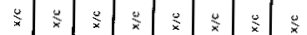

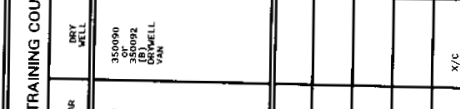

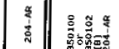

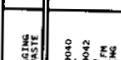

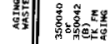

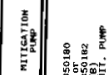

온

a

空

ธํำ

垶

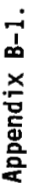

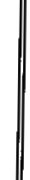

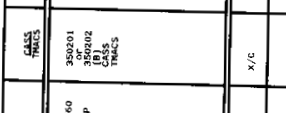

$\frac{0}{x}$

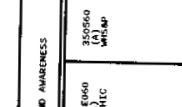

$y$ 

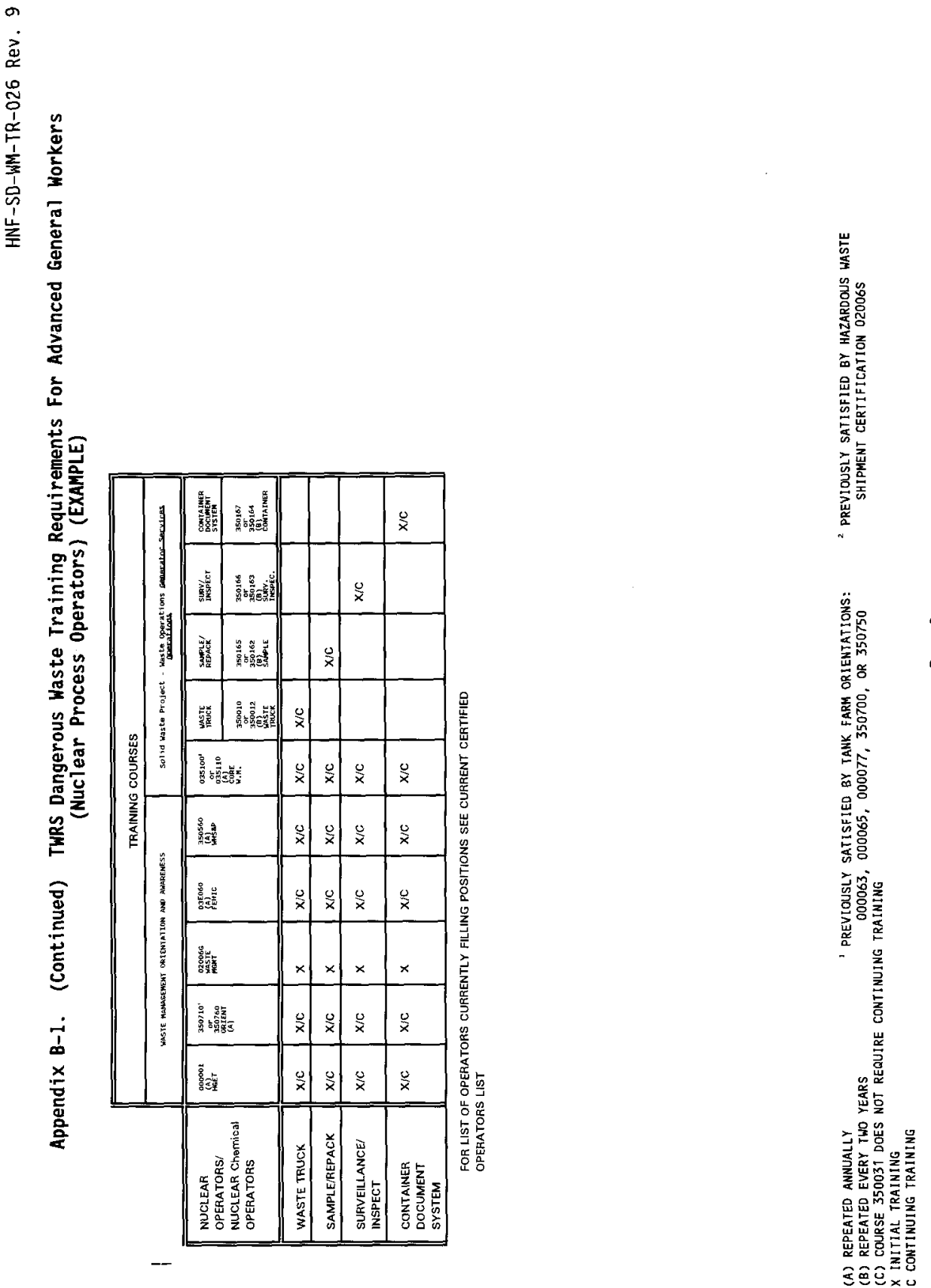
o

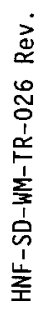

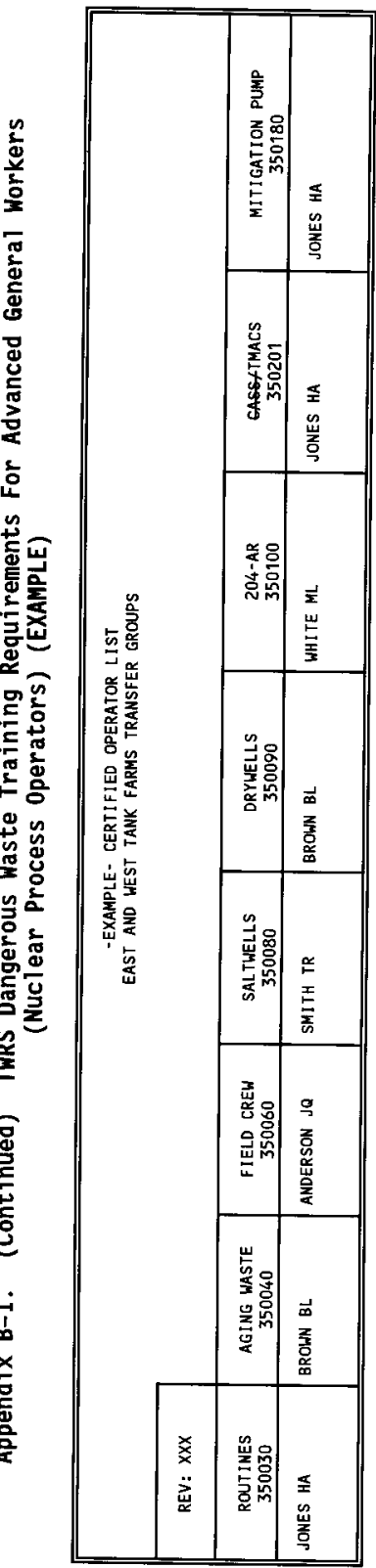

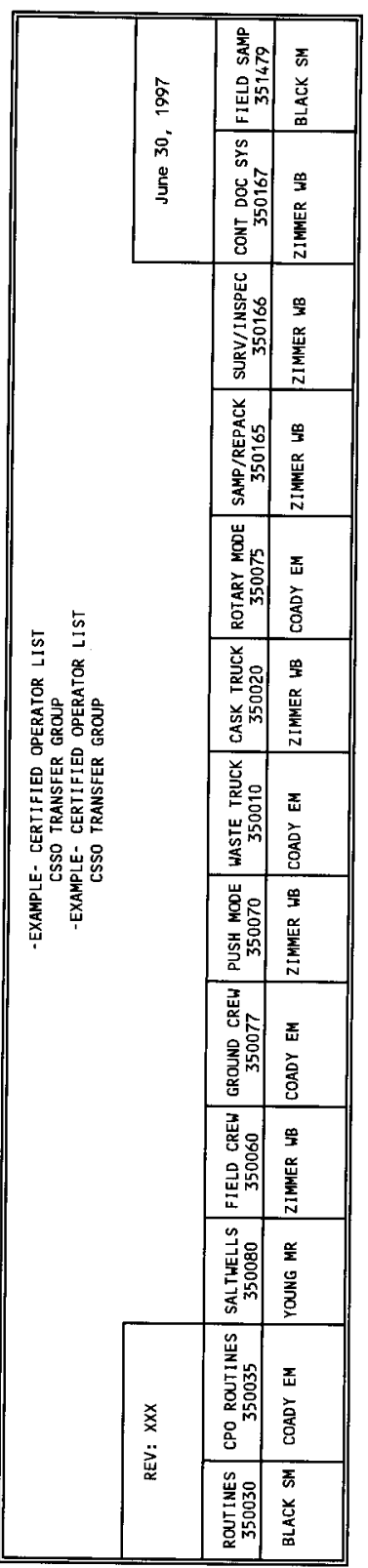




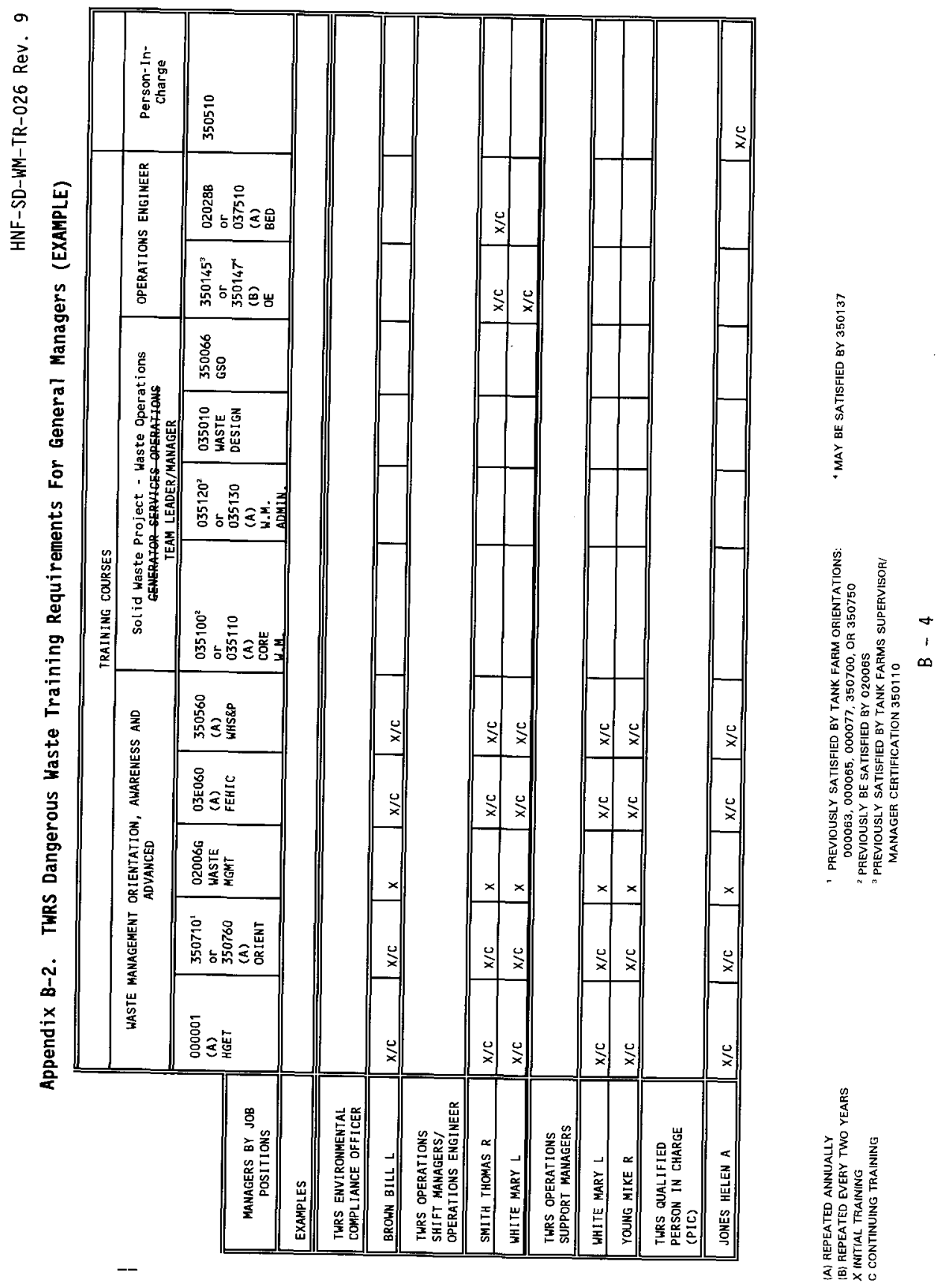




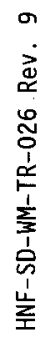

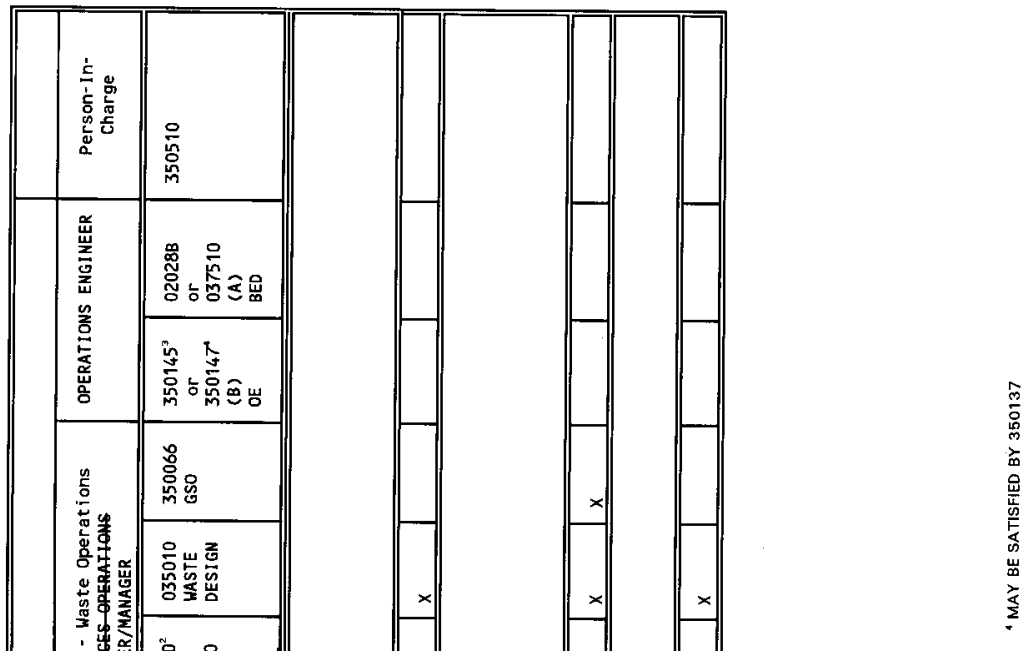

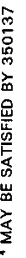
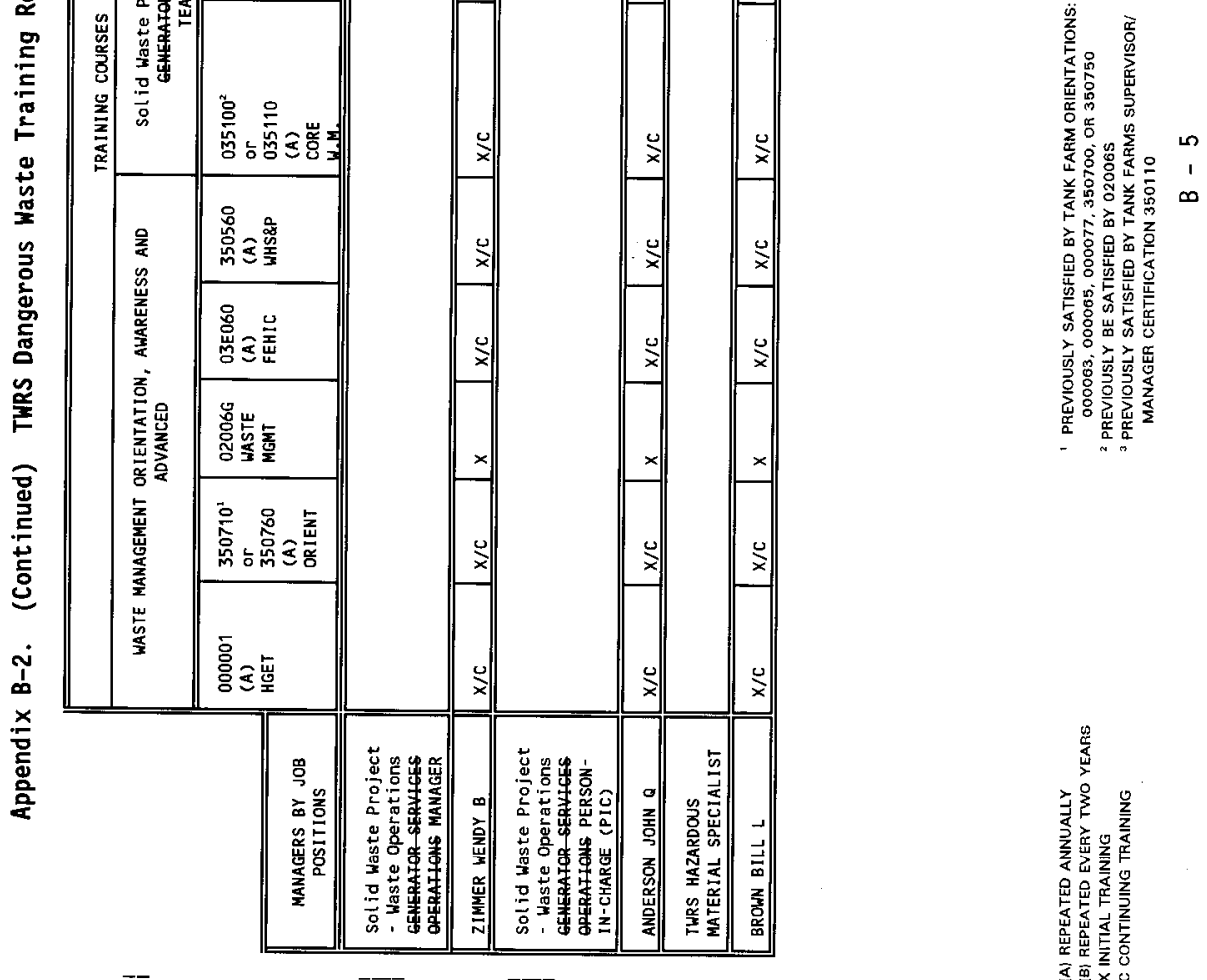


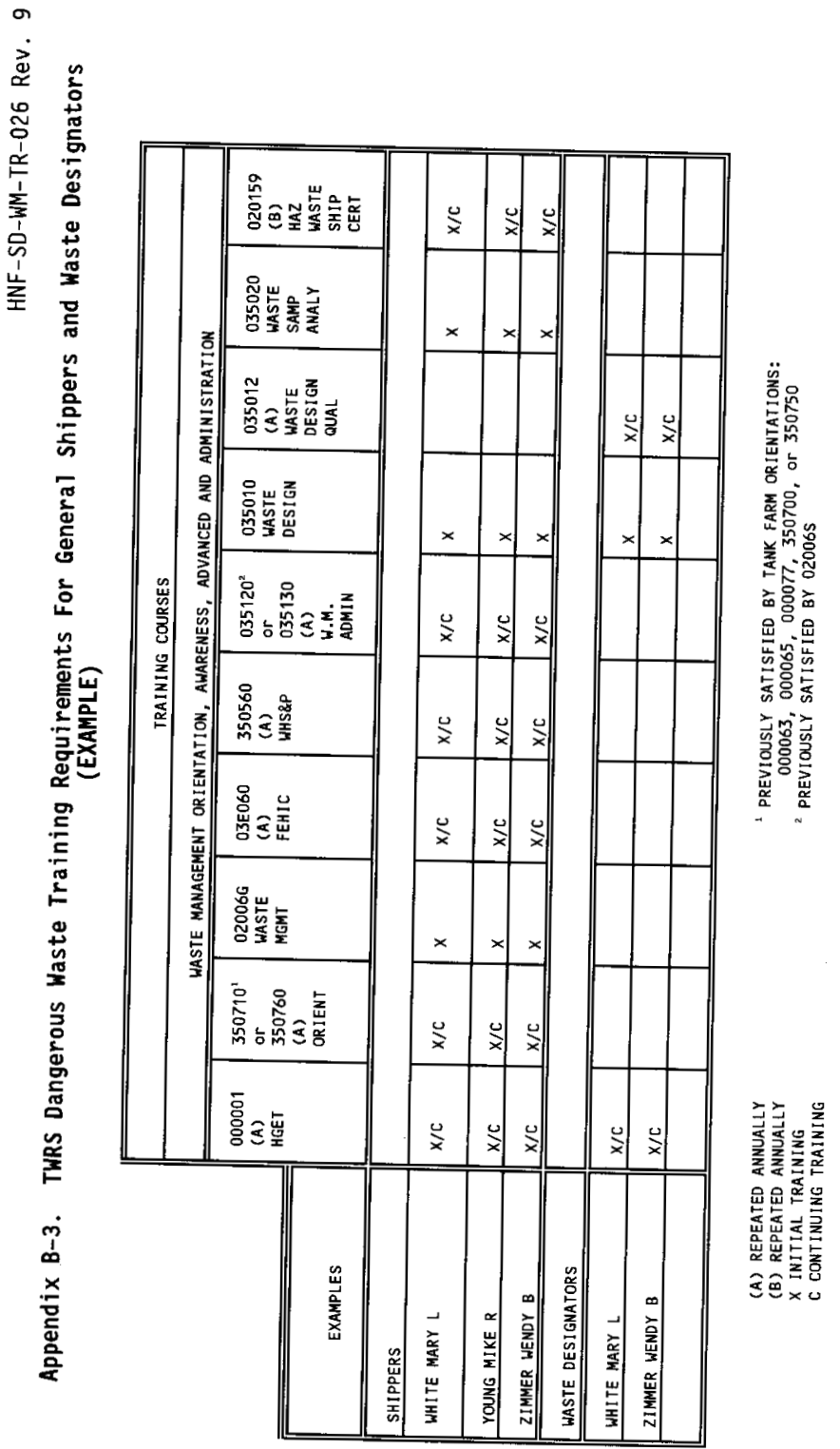

